\title{
The Microstructure of Polar Ice. Part I: Highlights from Ice Core Research ${ }^{\text {tr }}$
}

\author{
Sérgio H. Faria ${ }^{\mathrm{a}, \mathrm{b}, *}$, Ilka Weikusat ${ }^{\mathrm{c}}$, Nobuhiko Azuma ${ }^{\mathrm{d}}$ \\ ${ }^{a}$ Basque Centre for Climate Change (BC3), Alameda Urquijo 4-4, 48008 Bilbao, Spain \\ ${ }^{b}$ IKERBASQUE, Basque Foundation for Science, Alameda Urquijo 36-5, 48011 Bilbao, Spain \\ ${ }^{c}$ Alfred Wegener Institute for Polar and Marine Research, Columbusstrasse, 27568 Bremerhaven, \\ Germany \\ ${ }^{d}$ Department of Mechanical Engineering, Nagaoka University of Technology, \\ 1603-1 Kamitomioka, Nagaoka 940-2188, Niigata, Japan
}

\begin{abstract}
Polar ice sheets play a fundamental role in Earth's climate system, by interacting actively and passively with the environment. Active interactions include the creeping flow of ice and its effects on polar geomorphology, global sea level, ocean and atmospheric circulation, and so on. Passive interactions are mainly established by the formation of climate records within the ice, in form of air bubbles, dust particles, salt microinclusions and other derivatives of airborne impurities buried by recurrent snowfalls. For a half-century scientists have been drilling deep ice cores in Antarctica and Greenland for studying such records, which can go back to around a million years. Experience shows, however, that the ice-sheet flow generally disrupts the stratigraphy of the bottom part of deep ice cores, destroying the integrity of the oldest records. For all these reasons glaciologists have been studying the microstructure of polar ice cores for decades, in order to understand
\end{abstract}

\footnotetext{
${ }^{\sqrt{3}}$ Dedicated to the memory of Sigfús Jóhann Johnsen (1940-2013).

*Corresponding author. Tel.: +34-94-4014690.

Email addresses: sergio.faria@bc3research.org (Sérgio H. Faria), ilka.weikusat@awi.de (Ilka Weikusat), azuma@mech.nagaokaut.ac.jp (Nobuhiko Azuma) 
the genesis and fate of ice-core climate records, as well as to learn more about the physical properties of polar ice, aiming at better climate-record interpretations and ever more precise models of ice-sheet dynamics. In this Part I we review the main difficulties and advances in deep ice core drilling in Antarctica and Greenland, together with the major contributions of deep ice coring to the research on natural ice microstructures. In particular, we discuss in detail the microstructural findings from Camp Century, Byrd, Dye 3, GRIP, GISP2, NorthGRIP, Vostok, Dome C, EDML, and Dome Fuji, besides commenting also on the earlier results of some pioneering ventures, like the Jungfraujoch Expedition and the NorwegianBritish-Swedish Antarctic Expedition, among others. In the companion Part II of this work (Faria et al., this issue), the review proceeds with a survey of the state-ofthe-art understanding of natural ice microstructures and some exciting prospects in this field of research.

Keywords: ice, glacier, ice sheet, mechanics, creep, recrystallization, grain growth, microstructure, fabric, texture

\section{Introduction}

2 Ice is one of the oldest known minerals (Adams, 1990; Faria and Hutter, 2001) and manifests itself in diverse forms, most commonly as snow, frost, hail, icicles, ${ }_{4}$ ice plates, permafrost, firn, and massive polycrystals. Although it is neither as 5 ubiquitous as quartz nor as precious as diamond, ice is highly regarded by its 6 environmental and economic importance, as well as by the exceptionally large 7 deposits of "pure" ice found in continental-sized polar ice sheets (the impurity 8 content of polar ice typically lies in the ppb range; Legrand and Mayewski, 1997). 9 These ice sheets cover virtually all Greenland and Antarctica with more than $2.7 \times$ 
$10^{16} \mathrm{~m}^{3}$ of ice, corresponding to ca. $2.5 \times 10^{19} \mathrm{~kg}$ of freshwater, or $64 \mathrm{~m}$ of sea level rise equivalent (Lemke et al., 2007).

Like any usual crystalline solid, ice undergoes creep at sufficiently low stresses and temperatures higher than around half of its pressure melting point (Petrenko and Whitworth, 1999; Durham et al., 2001). Seeing that temperatures naturally occurring on Earth generally lie within that range, it should be no wonder for contemporary scientists to witness glaciers and ice sheets creeping slowly under their own weight. Notwithstanding, more often than not one still can find expositions in the modern literature attributing the creep of glaciers and ice sheets to an odd fluidity of ice. Such a pseudodoxy is nourished by the charm of the old glaciological literature (beautifully described by Clarke, 1987 and Walker and Waddington, 1988), ancient beliefs (Adams, 1990; Faria and Hutter, 2001), and the long list of real peculiarities of this material, which range from its abnormally low mass density to the persistence of brittle properties up to its melting point (Hobbs, 1974; Petrenko and Whitworth, 1999; Schulson and Duval, 2009).

While the creep of large ice masses can itself be considered an unsurprising phenomenon, the microscopic mechanisms that drive it are far from trivial and have been challenging scientists for several decades. Here we review some of these studies, with special emphasis on polar ice from deep ice cores, and present an up-to-date view of the modern understanding of natural ice microstructures and the deformation processes that may have produced them.

This work is divided in two correlated publications. Here in Part I, we review the advances in the research on natural ice microstructures during the last eight decades, using deep ice cores from Antarctica and Greenland to draw the storyline. In the companion Second Part (Faria et al., this issue) - from now on 
called Part II- we discuss several aspects of our current understanding of natural ice microstructures, including deformation mechanisms, induced anisotropy, grain growth and recrystallization, among others. The whole review ends with a summary of key concepts in the form of a glossary, for quick reference (Appendix A of Part II).

For the sake of brevity, we concentrate attention here to a limited number of ice cores only, which we consider most representative of the advances in ice microstructures occurring in a given period. Inevitably, in some situations we have faced the dilemma of choosing between two or more cores equally relevant within the same period. In such cases we have given preference to the core with the largest amount of information available for us. Admittedly, this pragmatic attitude generates a selection bias towards those ice coring projects we have been directly or indirectly involved with. Information about other important polar ice cores, not discussed here (e.g. Law Dome, Taylor Dome, Siple Dome, Talos Dome, WAIS, NEEM and others), is available in the review by Bentley and Koci (2007) and in the Ice Core Gateway of the U.S. National Oceanic and Atmospheric Administration (NOAA; http://www.ncdc.noaa.gov/paleo/icecore), among other resources.

Summaries of the most relevant microstructural, geophysical, and geographical data about the ice cores discussed here are given in Table B.1 and Figs. A.1A.3.

Remark 1. For the description of ice cores we adopt here the convention from top to bottom, unless explicitly specified otherwise. In usual cases of ordered stratigraphy, this convention implies inverse chronological order, viz. from younger to older. It is in this sense that a phrase like "transition from the Holocene to the 
Last Glacial" may appear, indicating the fact that the Last Glacial is older than the Holocene. Climatologists may feel a bit uncomfortable with this convention, but it is the most logical choice for describing the physical features of an ice core.

\section{Early research in natural ice microstructures}

It is usually a great injustice to attribute a scientific innovation to a single person, team, or publication. Nevertheless, such a regrettable act is often justified by the fact that the human mind cannot easily grasp history unless the latter is reduced to a plain timeline decorated with milestones. In this vein, we apologetically commit such an injustice here by naming milestones that, in our opinion, exemplify well scientific trends in decisive periods of ice microstructure research.

\subsection{The Jungfraujoch Expedition}

We start with a field expedition that has not only boosted research in ice microstructures, but also marked a turning-point in the way Glaciology is organized today. Gerald Seligman, a former businessman and skillful ski-mountaineer, was president of the Ski Club of Great Britain and author of an influential treatise on snow structure (Seligman, 1936). That work motivated him to consider the role of ice microstructure in the metamorphism of snow into ice. With this aim he led in 1937 a pioneering party to study this process on the Jungfraujoch, Switzerland, which included John D. Bernal, F. Philip Bowden, T. P. Hughes, Max F. Perutz and Henri Bader (Remark 2).

Remark 2. It is impossible to overestimate the importance for modern Glaciology of the constellation of scientists involved in the Jungfraujoch Expedition. 
Bernal discovered (together with Ralf H. Fowler) the essential principles that determine the arrangement of atoms in the ice lattice (Bernal and Fowler, 1933), nowadays known as the ice rules. Bowden and Hughes laid the foundations of our modern understanding of the frictional behavior of snow and ice (Bowden and Hughes, 1939; Bowden, 1953). Perutz became one of the pioneers of the modern (non-Newtonian) theory of ice creep (Perutz, 1948, 1949, 1950a,b, 1953). Finally, Bader joined his Ph.D. supervisor Paul Niggli in the Swiss Snow and Avalanche Commission as snow crystallographer in 1935, soon turning into one of the key proponents of a permanent laboratory for snow and avalanche research in Davos, Switzerland, which quickly evolved (in 1943) to the renowned Swiss Federal Institute for Snow and Avalanche Research, SRF (Achermann, 2009). Bader left Switzerland prior to SRF's inauguration, however, moving to the Americas in 1938 to become, among other things, an international prime mover of polar deep ice coring (Bader, 1962; see also de Quervain and Röthlisberger, 1999; Langway, 2008). Seligman, on the other hand, was named in 1936 President of the newlyfounded Association for the Study of Snow and Ice, which after the World War II hiatus evolved to the British Glaciological Society (publisher of the influential Journal of Glaciology) and in 1962, still under Seligman's lead, to the (International) Glaciological Society.

The results of the Jungfraujoch Expedition have been published in four papers, describing various aspects of the crystallography, metamorphism, mechanics and thermodynamics of snow, firn and ice (Perutz and Seligman, 1939; Hughes and Seligman, 1939a,b; Seligman, 1941). As commented by Seligman (1941) in his general review of the Expedition:

The work of earlier investigators and my own had traced the transition 
of new powdery snow into hard firn snow, but no one had systematically studied how this white, air-filled firn turned into the blue air-free ice of the lower glaciers. This was the ground of the present research. Glacier movement had been supposed to play a part, and this had to be investigated, including of course the flow of the névé. My longcherished desire to use polarized light to reveal the detailed development of firn and ice crystals required the help of a crystallographer, which led to unexpected and valuable results. With the exception of a few desultory photographs polarized light had never been used: a surprising omission in glaciological research.

Details of these crystallographic investigations on the Jungfraujoch have been described by Perutz and Seligman (1939). Firn and ice samples were collected from the walls of crevasses or from grottoes and pits dug in the accumulation and ablation zones of the Great Aletsch Glacier and its surroundings. They prepared thin sections and determined crystalline orientations using a technique described by Bader et al. (1939) for snow studies. Among other results, Perutz and Seligman (1939) noticed a conspicuous microstructural contrast between the "small regular" crystallites of firn and the "large irregular" grains of ice. They observed a lattice preferred orientation in the upper meters of firn, with $c$-axes lying perpendicular to the glacier surface and gradually giving way to more isotropic ("random") $c$ axis distributions below a few tens of meters of depth. In the deeper ice, however, strong lattice preferred orientations could again be observed, suggesting that the effect of glacier flow on the ice microstructure could be to some extent compared to the mechanism of high-temperature creep in other polycrystalline materials, e.g. magnesium (Remark 3). In particular, in places where the ice was subjected 
to shear, the ice crystallites were oriented with their basal planes parallel to the direction of shear.

Remark 3. Comparisons between the mechanisms of high-temperature creep in ice and other polycrystalline materials would later pave the way for the painstaking mechanical tests conducted by John W. Glen $(1952,1955)$ and Samuel Steinemann $(1954,1958)$, which confirmed the suggestion by Perutz $(1949,1950 \mathrm{~b})$ that the flow of glaciers could be modeled by a power law, nowadays known as Glen's flow law. It is worth noticing that Glen was a Ph.D. student under supervision of Egon Orowan and Max Perutz in Cambridge, while Steinemann was a Ph.D. student under supervision of Paul Niggli and Ernst Brandenberger at the ETH Zurich.

According to Seligman (1941), Perutz proposed that grain growth in glaciers could come about through a process of dynamic recrystallization, in which "softer" grains well oriented for simple shear have lower free energy and grow at the expenses of "harder" grains that cannot yield to the imposed stresses.

After World War II, several studies similar to those performed by the Jungfraujoch party were conducted on various glaciers (e.g. Ahlmann and Droessler, 1949; Seligman, 1949; Bader, 1951; Rigsby, 1951, 1958, 1960). These investigations contributed to enriching the records of glacier microstructures, introducing new details, diversity, and complexity to the picture. They failed, however, to provide a consistent description of the microstructural evolution of natural ice. One crucial reason for this failure derives from the fact that the analyzed ice samples had in general no clear spatial or historical relation to each other, being usually collected from distinct pits and similar superficial excavations in the ablation zone of glaciers. From these investigations it soon became evident that a systematic study 
of natural ice microstructures could only be accomplished by extracting an ice core from the heart of a natural large ice body. Such an enterprise was however a formidable prospect for post-war scientists. New mechanical drilling technologies, specific for ice, had to be developed and the logistics of all equipment and research teams would have to be carefully planned and tested.

\subsection{The first shallow ice cores}

Eventually, in 1949 two independent international teams set off to distant global locations to start drilling the first two polar ice cores for glaciological studies. During the Norwegian-British-Swedish Antarctic Expedition (NBSAE) of 19491952, Valter Schytt (1958) and colleagues recovered an ice core of nearly $100 \mathrm{~m}$ from the Maudheim site on Quar Ice Shelf, Dronning Maud Land, Antarctica (Remark 4). Nearly simultaneously, within the 1949-1950 activities of the Juneau Ice Field Research Project (JIRP), Henri Bader cored to almost $100 \mathrm{~m}$ into the temperate Taku Glacier in Alaska (Miller, 1954; Langway, 2008). Both drilling actions proved to be extremely difficult, and the quality of the recovered ice cores was precarious. Notwithstanding, some physical properties of parts of these cores could be analyzed.

In particular, Schytt (1958) studied the crystallography of the whole Maudheim ice core in depth intervals of approximately $5 \mathrm{~m}$, therefore producing the first microstructural investigation of deep polar ice and of an ice shelf. He observed a smooth transition of firn into ice at 60-65 $\mathrm{m}$ depth, but a clear discontinuity in grain growth with depth below ca. $70 \mathrm{~m}$, with grain sizes increasing six times faster with depth than in the upper $70 \mathrm{~m}$. He interpreted this discontinuity as the boundary between ice produced by in-situ accumulation and ice supplied by the inland ice sheet. In the petrographic analysis, single and multiple maxima could 
be identified in the $c$-axis distributions of samples from distinct depths, with no general trend towards a well-established preferred orientation with depth.

Remark 4. During NBSAE's first winter, drilling was also performed by Bertil Ekström (Schytt, 1958). Unfortunately, by the end of the season Ekström and other two companions, Leslie Quar and John Jelbart, drowned in a track-driven vehicle accident (Mills, 2003). On account of this fatality, three ice shelves around Maudheim Station have been posthumously named after them.

\section{The first polar deep ice cores: IGY sites, Camp Century, Bird Station, Dye} 3

After the difficulties faced by the JIRP and NBSAE teams with the pioneering ice cores drilled in Alaska and Antarctica, as well as the subsequent (and equally problematic) drilling campaign on Central Greenland by the Expéditions Polaires Françaises, EPF, in 1950-1951 (Langway, 2008), glaciologists in the whole world became aware of not only the great potential, but also the great hurdles of deep ice coring.

\subsection{IGY ice cores}

Fortunately, the approaching of the Third International Polar Year (IPY) in 19571958, which was soon renamed the International Geophysical Year (IGY), helped stimulating the interest in big scientific enterprises in polar regions. Indeed, the U.S. National Academy of Sciences (NAS) Committee for the IGY soon adopted deep core drilling into polar ice sheets for scientific purposes as one of its highpriority, long-term research projects, and subsequently the National Science Foundation (NSF) tasked the U.S. Army Snow, Ice and Permafrost Research Establishment (SIPRE), under the leadership of Chief Scientist Henri Bader, with the 
responsibility for defining, developing, and conducting the entire U.S. ice core drilling and research program under a joint interagency agreement (Bader, 1962). As reported by Langway (1970, 2008), the SIPRE pre-IGY pilot drilling trials were conducted at Site-2, Northwest Greenland in 1956 (305 m) and 1957 (411 m), being closely followed by two IGY core drillings in Antarctica, the first at Byrd Station, in 1957-1958 (307 m) and the second at Little America V, on the Ross Ice Shelf, in 1958-1959 (264 m). This was a period of great technological improvements not only in drilling, but also in analytical methods (see e.g. Gow, 1963a,b; Langway, 1970). The success of the IGY drilling campaigns and the increasing quality of the recovered cores motivated NAS to assign SIPRE with the task of developing a post-IGY deep ice coring system capable of reaching bedrock depths. The outcome of this post-IGY project was a series of celebrated ice cores drilled by B. Lyle Hansen and his team, two of them reaching bedrock in Greenland (Camp Century) and Antarctica (Byrd Station), respectively.

\subsection{Camp Century}

The first deep polar ice core to reach the base of a polar ice sheet was retrieved from Camp Century, Northwest Greenland, in 1963-1966 (after two unsuccessful attempts in 1961-1963) and achieved a final length of 1375 m (Hansen and Langway, 1966). For the standards of that time, the physical quality of the core was very good, allowing the first continuous record of structure and chemical composition of a polar ice sheet, stretching from surface to bedrock. More than this, it delivered the definite proof that the combination of ice core drilling with oxygen isotope analysis was indeed a valuable method for reconstructing Earth's past climate (Dansgaard et al., 1969).

Measurements of grain sizes and $c$-axis orientations started on the field, in 
1961, but a thorough microstructural analysis of the whole core was accomplished and published only 16 years later (Herron and Langway, 1982; Fig. A.2; a preliminary crystallographic investigation of the bottom $16 \mathrm{~m}$ of Camp Century's debrisladen basal ice appeared somewhat earlier, viz. Herron and Langway, 1979). Circa 50 horizontal and six vertical thin sections, covering the whole Camp Century core at variable depth intervals, were prepared for crystallographic studies by sectioning thick samples with a microtome. Grain sizes were usually measured from photographs using a semi-automatic particle size analyzer for detecting crosssectional areas, whereas in difficult cases (e.g. sections contained too large or too complex grains) this method was replaced by counting crystallites within a given area. Crystalline $c$-axis orientations were measured on a Rigsby universal stage (essentially an enlarged version of the conventional four-axis universal stage, especially designed for the larger crystallites found in natural ice; Rigsby, $1951,1958)$ and presented in a variety of ways, from contoured pole figures to resultant directional vectors and statistical parameters derived from eigenvalues and -vectors.

In the upper hundreds of meters of the Camp Century core Herron and Langway (1982) observed a thirty-fold increase in the average grain cross-sectional area to more than $100 \mathrm{~mm}^{2}$ at $700 \mathrm{~m}(\approx 3 \mathrm{kaBP}$, according to Dansgaard and Johnsen, 1969), with grain shapes turning gradually more complex and interlocking. Below $850 \mathrm{~m}$ the average grain size decreases to less than $60 \mathrm{~mm}^{2}$ at $1000 \mathrm{~m}$ depth, followed by a drastic size reduction to ca. $2 \mathrm{~mm}^{2}$ within a very short depth interval (1136-1149 m depth), which coincides with the climatic transition from the Holocene interglacial to the Last Glacial period (interglacial-glacial transition; Dansgaard and Johnsen, 1969). This sudden reduction in grain size is eventually 
followed by a gradual increase to about $20 \mathrm{~mm}^{2}$ at $1300 \mathrm{~m}$ depth, which abruptly gives way to an extremely fine-grained (ca. $0.6 \mathrm{~mm}^{2}$ ) debris-laden ice at the bottom $10 \mathrm{~m}$ of the core (Herron and Langway, 1979).

Preferred $c$-axis orientations were identified to evolve with depth towards a strong vertical single maximum at the bottom of the core, with a marked enhancement within the depth interval 1136-1149 m corresponding to the interglacialglacial transition. The fine-grained and highly oriented crystallites in the lowest $10 \mathrm{~m}$ of the core suggest a zone of high deformation on a frozen bed, which is consistent with estimated temperature of $-13^{\circ} \mathrm{C}$ at the ice-bedrock interface (Hansen and Langway, 1966; Herron and Langway, 1979).

\subsection{Byrd Station}

After successfully finishing core retrieval at Camp Century in July 1966, the same party headed for south and started core drilling at Byrd Station, Antarctica, in November 1966. In less than two field seasons, Hansen and his team managed to recover a total core length of $2164 \mathrm{~m}$, reaching bedrock in January 1968. Shortly after, however, good luck turned its back on them, as they lost their valued drill rig stuck in frozen subglacial water, which upwelled into the hole while the drill was pinching the bed (Ueda and Garfield, 1970). Fortunately, the entire ice core was already retrieved and safe, and could provide the most complete portrait of Antarctic ice to that date.

Gow and Williamson (1976) performed the crystallographic analysis of the Byrd deep ice core (Fig. A.3). The methods of microstructural investigation were generally similar to those employed on the Camp Century core (Sect. 3.2). From the firn-ice transition zone at $56 \mathrm{~m}$ depth down to ca. $600 \mathrm{~m}(\approx 5.5 \mathrm{kaBP}$, according to Hammer et al., 1994) they observed a twenty-fold increase in the average 
grain cross-sectional area, with the average grain size stabilizing at about $60 \mathrm{~mm}^{2}$. Concomitantly, the regular polygonal grain structure just below the firn-ice transition gradually gives way to a complex structure of interlocking grains, frequently showing undulose extinction and similar manifestations of lattice distortion. At $1200 \mathrm{~m}$ depth the core reaches the glacial-interglacial transition and the grain size stability breaks down with a marked three-fold decrease in grain size within a depth interval of only 100 meters. The resulting fine-grained structure persists for further $500 \mathrm{~m}$, in a zone characterized by intense ash layers and widespread cloudy bands (Fig. A.4 and Appendix A of Part II). Below 1600 m depth the finegrained structure starts becoming disturbed by interdigitations of coarse-grained ice, which eventually overrides the ice microstructure beneath $1800 \mathrm{~m}$ depth, with increasingly large crystallites reaching sizes of several thousands of $\mathrm{mm}^{2}$ at the bottom of the core.

The depth development of $c$-axis preferred orientations in the upper $1800 \mathrm{~m}$ of the Byrd deep ice core follows roughly that of Camp Century: a gradual but persistent formation of a vertical single maximum. By analyzing the microstructure of deep ice in greater detail, Gow and Williamson (1976) discovered a consistent relation between grain size, c-axis preferred orientations, and impurity content, such that the higher the impurity content, the smaller are the grains and the stronger is the vertical single maximum. As a consequence, the fine-grained cloudy bands in the depth range 1200-1800 m of the Byrd core are generally associated with a strong single-maximum $c$-axis distribution, while the $c$-axis preferred orientations of the coarse-grained ice, intermixed in that depth range and pervasive below $1800 \mathrm{~m}$ depth, are characterized by multiple maxima.

In many aspects, the Byrd deep ice core established new standards for our 
understanding of the physics and microstructures of polar ice sheets. First, the observed general evolution of grain sizes and $c$-axis orientations with depth established the basis for the (overused) tripartite paradigm of polar ice microstructure, also known as the "three-stage model" (cf. Sect. 5 and Appendix A of Part II; the formulation below follows De la Chapelle et al., 1998):

1. in the upper hundreds of meters of an ice sheet, grains grow in the regime of Normal Grain Growth (NGG; Stephenson, 1967; Gow, 1969);

2. in intermediate depths, NGG is counterbalanced by grain splitting via "polygonization" (Alley et al., 1995);

3. at the bottom of the ice sheet, where the ice temperature raises above ca. $-10^{\circ} \mathrm{C}$, dynamic recrystallization with nucleation of new grains (SIBM-N) markedly transforms the microstructure (Duval et al., 1983).

Second, the highly oriented fine-grained structure of the impurity-rich glacial ice in the depth interval 1200-1800 m suggested that horizontal simple shearing is considerably strong in that zone. This finding prompted a question, colloquially epitomized by the title of Stan Paterson's (1991) article, which has pervaded ice core studies ever since: "Why is glacial ice sometimes soft?" Actually, the first step towards answering this question has been taken by Gow and Williamson (1976) themselves. They reported the existence and basic properties of cloudy bands (see Appendix A of Part II), and identified them as one of the major stratigraphic features of glacial ice. They noticed also that the fine-grained structure and high anisotropy of such bands disclose them as localized zones of intense shearing, which may possibly be major contributors to the flow of the ice sheet. Such extensive shearing along discrete strata situated well above bedrock could cause differential layer thinning and seriously distort the stratigraphy, making the 
dating and interpretation of climate records extremely complicate. Today, cloudy bands continue to challenge our understanding of ice mechanics and microstructure, with novel methods of observation and modeling casting new light on this issue (Takata et al., 2004; Lhomme et al., 2005; Svensson et al., 2005; Gow and Meese, 2007; Faria et al., 2009, 2010).

Finally, the danger of unexpected subglacial water upwelling into the borehole would not only become a recurrent source of troubles for future deep ice core drillings (see next sections), but also a presage of the unexpected extension and dynamics of the subglacial hydrologic environment (Clarke, 2005; Siegert, 2005; Evatt et al., 2006; Wingham et al., 2006).

\subsection{Dye 3}

The successful operations at Camp Century and Byrd Station proved that core drilling down to the bedrock through several kilometers of creeping polar ice was feasible, and that the physical and environmental information recorded in ice cores was invaluable. These results motivated researchers from Denmark, Switzerland and the United States to meet in 1970 in order to plan a new major research program for ice core drilling in Greenland, named GISP: the Greenland Ice Sheet Program. Originally, GISP was a very ambitious eleven-year program involving three deep ice core drillings down to bedrock, but budgetary restrictions forced the program to reduce deep bedrock drilling to only one location, the Summit, in North-Central Greenland (Langway, 2008). Eventually, however, further financial restrictions compelled the selection of a logistically more convenient site in Southern Greenland, at the U.S.A.F. Distant Early Warning Radar Station Dye 3 (Dansgaard et al., 1982). Drilling started at Dye 3 in 1979, after seven years of preliminary field and laboratory studies, and in 1981 the newly designed Danish 
electromechanical drill ISTUK touched bedrock at $2037 \mathrm{~m}$. Several on site laboratories (including two equipped science trenches and a clean-room trailer) and new processing procedures established new standards of organization and efficiency for deep ice core field studies.

Vertical thin sections were sampled by Herron et al. (1985) on site, at approximately $100 \mathrm{~m}$ depth intervals throughout the core, and prepared them for crystallographic analyses following the procedures already adopted in previous ice core studies (e.g. Herron and Langway, 1982). Average grain sizes were determined using the intercept method. Crystalline $c$-axis orientations were measured at 23 selected depths using a Rigsby universal stage and were presented in a variety of ways, following nearly the approach already adopted in the Camp Century studies (cf. Sect. 3.2). These $c$-axis observations were also compared with the results of an alternative method for monitoring material anisotropy through ultrasonic velocity measurements of selected ice core samples.

Herron et al. (1985) observed (cf. Fig. A.2) a ten-fold increase in the average grain cross-sectional area to ca. $30 \mathrm{~mm}^{2}$ at $800 \mathrm{~m}(\approx 2 \mathrm{kaBP}$, according to Reeh, 1989), followed by a size reduction in the next $100 \mathrm{~m}$ and subsequent grain size stabilization around an average cross-sectional area of $16 \mathrm{~mm}^{2}$. Finally, at the interglacial-glacial transition at ca. $1785 \mathrm{~m}$ depth (Dansgaard et al., 1982; Gundestrup and Hansen, 1984), the average grain size sharply reduces to less than $0.5 \mathrm{~mm}^{2}$ within some tens of meters, and then resumes its growth trend with depth down to bedrock, reaching ca. $5 \mathrm{~mm}^{2}$ at the bottom of the core (where the temperature is around $-13^{\circ} \mathrm{C}$; Gundestrup and Hansen, 1984), A general tendency to horizontally elongated grains was observed throughout the core, especially in coarse-grained ice (where the grain aspect ratio can reach 1.3). 
Crystallographic and ultrasonic measurements of the Dye 3 core revealed a trend similar to previous deep ice cores, especially the Byrd Station core, with a steady reorientation of $c$-axes towards vertical and a marked vertical single maximum below the interglacial-glacial transition at $1785 \mathrm{~m}$ depth. More detailed grain size and $c$-axis measurements conducted by Langway et al. (1988) in glacial ice from 1785-2037 $\mathrm{m}$ depth showed that the strong vertical single-maximum $c$ axis distribution persists throughout this lower portion of the core, with grain sizes varying between 0.2 and $7 \mathrm{~mm}^{2}$. Smaller grains were found in high-impurity layers and, conversely, larger grains were found in low-impurity strata. In contrast to the Camp Century and Byrd cores (cf. Sects. 3.2 and 3.3), Langway et al. (1988) reported that, in the Dye 3 core, impurity content seemed to have a strong influence on grain sizes, but less of an effect on $c$-axis preferred orientations.

\section{News from Greenland: GRIP, GISP2, NGRIP}

While U.S. polar deep drilling operations could be successfully performed since the late 1950's, thanks in part to exclusive scientific programs organized by the National Academy of Sciences (NAS) and the National Science Foundation (NSF), the nations of post-war Europe had first to organize themselves in a stable politicoeconomical framework, in order to allow the creation of exclusive European programs capable of financing such complex and expensive scientific enterprises. In this vein, the 1970's and 1980's constituted a period of remarkable changes in the European scientific landscape. The first United Nations Conference on the Environment, held in Stockholm in 1972, motivated the European Commission (EC) to launch its first Environment Action Program (EAP), the earliest of a series of fiveyear action programs for dealing with critical environmental issues. In 1974 the 
European Science Foundation (ESF) was created, and in 1986 the ESF launched its Polar Science Network Program.

These specific European programs for climate and environment established the grounds for the creation of successful European deep drilling projects in polar regions, through collaborative funding schemes involving the EC, ESF, and several national funding agencies.

\subsection{GRIP}

The decisive contributions of Denmark and Switzerland to the success of GISP led European glaciologists to propose to ESF the creation of a long term program for promoting glaciological research. In 1988 the ESF agreed and launched the European Glaciological Program (EGP). The first project within this program was the Greenland Ice Core Project (GRIP), which aimed at drilling to bedrock a deep ice core at the highest point of the Greenland Ice Sheet, the Summit (the site originally selected for GISP, cf. Sect. 3.4), for investigating the climatic and environmental changes of the past 250,000 years (GRIP community members, 1996). Nearly at the same time, a U.S. companion project called GISP2 would pursue similar objectives at a site just $27 \mathrm{~km}$ to the west (cf. Sect. 4.2).

Funding of GRIP came initially from national funding agencies of the eight participating European nations (Denmark, Switzerland, France, Germany, United Kingdom, Italy, Iceland and Belgium). This was soon complemented by financial support of the European Commission under the European Program on Climatology and Natural Hazards (EPOCH). Drilling and logistic operations were coordinated by the GRIP Operation Center (GOC), which was established for this purpose at the Geophysical Institute of the University of Copenhagen. Drilling started in summer 1990, using an updated version of the ISTUK drill, and stopped 
in July 1992, after penetrating through $6 \mathrm{~m}$ of debris-laden (silty) ice just above bedrock, at a depth of $3028.8 \mathrm{~m}$ below surface (Johnsen et al., 1994). Unfortunately, due to severe stratigraphic disturbances caused by the ice flow in the lowest $10 \%$ of the core, reliable dating has been limited to depths ca. $300 \mathrm{~m}$ above bedrock ( $\approx 110$ kaBP; Peel, 1995; Landais et al., 2003), although tentative chronological reconstructions of the disturbed bottom ice do exist (Landais et al., 2003; Suwa et al., 2006).

More than 60 vertical and horizontal thin sections were sampled on site at irregular intervals, ranging from 10 to $115 \mathrm{~m}$ in the upper $770 \mathrm{~m}$, and from 25 to $55 \mathrm{~m}$ in the rest of the core (Thorsteinsson et al., 1997). The samples were prepared for crystallographic analysis following the already standard methods used in previous ice core studies. Further sampling of core depths of special interest was done later, at the storage facility in Copenhagen.

Average grain sizes were measured directly, mainly from vertical thin sections, using the linear intercept method. Crystalline $c$-axis orientations were determined mostly from horizontal thin sections using a semi-automatic Rigsby universal stage (Lange, 1988). The results were analyzed by a special software and presented in a variety of ways, from point scatter pole figures to median inclinations and statistical parameters derived from eigenvalues and -vectors.

Thorsteinsson et al. (1997) observed (cf. Fig. A.2) a steady and regular development of preferred $c$-axis orientations with depth towards a single vertical maximum distribution, which is compatible with the stress regime in an ice dome, viz. dominated by uniaxial vertical compression. In contrast to the Camp Century and Byrd cores (cf. Sects. 3.2 and 3.3), no significant strengthening of the single maximum distribution could be recognized at the interglacial-glacial transition 
depth.

GRIP's grain size development with depth, as observed by Thorsteinsson et al. (1997), are comparable to those previously reported for Camp Century, Dye 3 and Byrd: an eight-fold increase in average grain cross-sectional area below $100 \mathrm{~m}$ depth to ca. $10 \mathrm{~mm}^{2}$ at $700 \mathrm{~m}$ depth $(\approx 3.5 \mathrm{kaBP}$, according to Dansgaard et al., 1993), followed by a stable mean grain size in the remaining part of the Holocene interglacial ice. At the interglacial-glacial transition the average grain size reduces to half, and continues to decrease with depth to ca. $3 \mathrm{~mm}^{2}$ at $1980 \mathrm{~m}$. Further down, grain size starts to moderately increase again, reaching ca. $15 \mathrm{~mm}^{2}$ at $2790 \mathrm{~m}$ depth, in early glacial ice close to the transition to the Eemian interglacial. In the bottom $250 \mathrm{~m}$ of the core, where the climate records are disturbed by the ice flow (Taylor et al., 1993; Peel, 1995; see also Sect. 4.2), the average grain size varies dramatically between less than $12 \mathrm{~mm}^{2}$ and more than $300 \mathrm{~mm}^{2}$ (Thorsteinsson et al., 1995), revealing a conspicuous correlation with impurity concentration changes (which in turn are related to climatic contrasts). A general tendency to horizontally elongated grains was observed throughout the core, with grain aspect ratios lying in the range 1.1-1.4.

The similarity of GRIP's grain size profile with previous deep ice cores was interpreted as a corroboration of the tripartite paradigm of polar ice microstructure ("three-stage model"; see Sect. 3.3), even though the $c$-axis preferred orientations found in the deepest $250 \mathrm{~m}$ of the GRIP core did not correspond to the expected LPO in the recrystallization regime.

\subsection{GISP2}

After several years of planing, the U.S. Greenland Ice Sheet Project II (GISP2) was officially initiated in late 1988 by the Division of Polar Programs (DPP, now 
Office of Polar Programs) of NSF. It was developed as the first project of the new Arctic System Science Program (ARCSS), a DPP initiative focusing on environmental change in the Arctic. The scientific activities of GISP2 were coordinated by the GISP2 Science Management Office at the Climate Change Research Center of the University of New Hampshire, while logistics and drilling were organized by the Polar Ice Coring Office (PICO) at the University of Nebraska (1987-1989) and the University of Alaska Fairbanks (1989-1993).

The objectives of GISP2 were essentially similar to those of its companion European project GRIP (see Sect. 4.1): drilling down to bedrock a deep ice core at Summit, the location originally selected for GISP (cf. Sect. 3.4), in order to investigate climatic and environmental changes back to the Eemian interglacial. The fact that the GRIP and GISP2 drilling sites were so near (just $28 \mathrm{~km}$ apart) implied a great advantage not only for logistics, but also for the ice core analysis, since the records of the two cores could be used to validate each other. The harmony and partnership between European GRIP and U.S. GISP2 scientists was not only paramount for facilitating the logistics and validation procedures, but it became also a paragon for future international drilling projects.

Drilling started in summer 1989 and terminated in July 1993, after drilling $3053.4 \mathrm{~m}$ of ice and almost $1.6 \mathrm{~m}$ of bedrock material (Gow et al., 1997). As in the case of the GRIP core, severe stratigraphic disturbances caused by the ice flow in the lowest $10 \%$ of the core limited reliable dating to depths ca. $300 \mathrm{~m}$ above bedrock ( $\approx 110$ kaBP; Peel, 1995), although tentative chronological reconstructions of the disturbed bottom ice do exist (Suwa et al., 2006).

More than 500 vertical and horizontal thin sections were sampled at $20 \mathrm{~m}$ intervals from 94 to $1501 \mathrm{~m}$ depth, and thereafter at $10 \mathrm{~m}$ intervals down to $3053 \mathrm{~m}$, 
together with some additional sections for particular studies (Gow et al., 1997). The samples were prepared for crystallographic analysis following standard techniques applied in previous ice core studies. Crystalline $c$-axis orientations were determined with a usual Rigsby universal stage, and presented as point scatter pole figures. Average grain sizes were measured from photographs of the sections between crossed polarizers using two distinct methods: linear intercepts for vertical sections, and measurements of the 50 largest grains in horizontal sections.

The GISP2 grain size analysis presented by Gow et al. (1997) is very interesting, in the sense that its comparison of different methods reveals the degree of subjectivity which ice core microstructure studies are often exposed to (Fig. A.2). The linear intercept method led Woods (1994), Alley and Woods (1996), and Gow et al. (1997) to identify four regimes of grain size development with depth, which are to some extent similar to those reported for Camp Century, Dye 3, Byrd, and GRIP. In Regime 1 the average grain cross sectional area undergoes a tenfold increase within $600 \mathrm{~m}$ (which corresponds to a roughly linear growth with age), reaching ca. $9 \mathrm{~mm}^{2}$ at $700 \mathrm{~m}$ below surface $(\approx 3.2 \mathrm{kaBP}$, according to Meese et al., 1997). In the subsequent Regime 2, the mean grain size remains somewhat stable, with a very slight decreasing trend. This stability is abruptly terminated in Regime 3, which starts at the interglacial-glacial transition (at around $1680 \mathrm{~m}$ depth) with a more than twofold grain size reduction within nearly $200 \mathrm{~m}$. Thereafter, mean grain size follows a slight increasing trend that extends over more than $1000 \mathrm{~m}$. Nevertheless, this impurity-rich glacial ice remains generally finegrained. At a depth of about $2750 \mathrm{~m}$ (close to the transition to the Eemian interglacial), however, the first layers of clear, coarse-grained ice begin to appear, betokening critical stratigraphic disturbances (Peel, 1995; cf. Sect. 4.1) and the 
emergence of Regime 4. With thicknesses varying between tens to hundreds of millimetres, such coarse-grained ice strata become very frequent around $2950 \mathrm{~m}$ depth, making the ice close to bedrock very clear, with crystallites as large as $1000 \mathrm{~mm}^{2}$ of cross-sectional area. The basal $13 \mathrm{~m}$ of the ice sheet are nonetheless composed of fine-grained silty ice.

In contrast, the grain size dataset produced by Gow et al. (1997) via measurements of the 50 largest grains in each sample revealed a somewhat different picture. Four key regimes could still be identified, which are qualitatively similar to those determined with the linear intercepts method, but grain size magnitudes, variability, and rates of change, as well as the depths delimiting the key regime zones, are different. In the upper zone, which corresponds to Regime 1 and extends from 100 to $1000 \mathrm{~m}$ depth, mean grain size increases steadily from $4.5 \mathrm{~mm}^{2}$ to $22-50 \mathrm{~mm}^{2}$. It remains within this wide range throughout the second zone, which corresponds to Regime 2. Thus, as observed with the linear intercept method, the stability of Regime 2 is abruptly terminated at around $1680 \mathrm{~m}$ depth (the interglacial-glacial transition), with a more than twofold grain size reduction to $11-21 \mathrm{~mm}^{2}$ within nearly $200 \mathrm{~m}$, which marks the beginning of Regime 3. Below $2300 \mathrm{~m}$ the average grain size shows again a slight increase, reaching ca. $25 \mathrm{~mm}^{2}$ in the end of the third zone, at $2990 \mathrm{~m}$ depth. Below that depth and down to $13 \mathrm{~m}$ above bedrock one finds the fourth zone, corresponding to Regime 4, where grains become huge, often exceeding $1000 \mathrm{~mm}^{2}$ of crosssectional area. Gow et al. (1997) remarked that, in their opinion, the 50 largest grains method produced a grain size profile more similar to that observed at the Byrd core (Sect. 3.3).

As in the case of GRIP, the similarity of GISP2's grain size profile with previ- 
ous deep ice cores was interpreted as a corroboration of the tripartite paradigm of polar ice microstructure ("three-stage model”; see Sect. 3.3).

Crystallographic measurements of the GISP2 core revealed a development of preferred $c$-axis orientations with depth roughly similar to those already observed in other deep ice cores (GRIP, Byrd, Dye 3, Camp Century), but with some important differences in the details. Gow et al. (1997) report a progressive reorientation of $c$-axes towards the vertical, including a strong clustering of $c$-axes beneath the interglacial-glacial transition (at $1680 \mathrm{~m}$ depth). In the bottom $300 \mathrm{~m}$ of the core, where stratigraphic disturbances become critical and layers of coarse-grained material start to appear, the $c$-axes in the coarse-grained strata show significant deviations from the strong vertical single maximum, tending to exhibit a broad or girdle-like $c$-axis distribution around the vertical. It should be remarked, however, that Thorsteinsson et al. (1997) observed no sharp contrast in the $c$-axis distributions in the interglacial-glacial transition zone of the GRIP core, and that the zone of recrystallized, coarse-grained basal ice at Byrd Station (where pressure melting conditions occur at the bed) is much thicker than at the GRIP and GISP2 sites, where bottom ice temperatures are about $-9^{\circ} \mathrm{C}$.

An interesting feature of the crystallographic observations of the GISP2 core was the discovery of crystal striping below ca. $2200 \mathrm{~m}$ depth (Alley et al., 1997), identified in thin sections as stripes of crystallites with $c$-axis preferred orientations very distinct from the surrounding ice matrix, and believed to be formed during the process of folding. In fact, visual stratigraphy analyses of the GISP2 core revealed that first signs of wavy strata already appear at around $2200 \mathrm{~m}$, centimeter-sized overturned folds are found below $2400 \mathrm{~m}$, and clear evidences of large-scale stratigraphic disturbances (affecting at least meters of core) occur at 
the bottom $10 \%$ of both GRIP and GISP2 cores (Taylor et al., 1993; Gow et al., 1997).

\subsection{NGRIP}

In spite of the of the many scientific breakthroughs and invaluable climatic information provided by the two Greenlandic deep ice cores from the Summit area (GRIP and GISP2), the severe disturbances in the Eemian climate records of these two cores posed an unwelcome setback for polar paleoclimatology. This disappointing situation prompted the search for a new drilling site, which should contain undisturbed ice from the Eemian interglacial period. Based on radio-echo sounding profiles and geophysical models (Dahl-Jensen et al., 1997), a site on an ice ridge $325 \mathrm{~km}$ north-northwest of the Summit was eventually selected for what would be known as the North Greenland Ice Core Project (NGRIP, or NorthGRIP).

Support for NGRIP came from diverse funding agencies in Denmark (SNF), Belgium (FNRS-CFB), France (IPEV and INSU/CNRS), Germany (AWI), Iceland (RannIs), Japan (MEXT), Sweden (SPRS), Switzerland (SNF) and the USA (NSF, Office of Polar Programs). This established NGRIP as a truly multi-continental (America, Asia and Europe) deep ice core drilling program, which was directed and organized by the Niels Bohr Institute of the University of Copenhagen (DahlJensen et al., 2002).

Drilling started in summer 1996, and bedrock was reached at $3085 \mathrm{~m}$ depth in July 2003 (NorthGRIP members, 2004). Thanks to an unexpectedly intense geothermal heat flux in North Greenland (within the range 50-200 mW/m² ; DahlJensen et al., 2003), it turned out that the basal melting rate at NGRIP ( $>7 \mathrm{~mm} / \mathrm{a}$ ) is high enough to lubricate the bed, therefore minimizing stratigraphic disturbances caused by simple-shearing flow at the bottom of the ice sheet. Conse- 
quently, in contrast to the serious stratigraphic disruptions observed at the bottom of GRIP and GISP2 (Sects. 4.1 and 4.2), the NGRIP paleoclimate records back to the transition to the Eemian interglacial are unusually thick and well preserved. Unfortunately, the price paid for such nice paleoclimate records is very high: the intense geothermal heat flux melted away most of the Eemian ice, limiting the NGRIP age to $123 \mathrm{kaBP}$ (NorthGRIP members, 2004).

An important feature of the NGRIP core is that it became the first deep ice core to have part of its visual stratigraphy (within the depth interval 1330-3085 m) recorded with a new German-Danish automated Ice-core Line-Scanner (ILS; DahlJensen et al., 2002; Svensson et al., 2005; see Fig. A.4). It was also the first deep ice core to have some thick sections investigated with a prototypical version of the automated optical microscopy and image analysis method later known as Microstructure Mapping (Kipfstuhl et al., 2006; also Fig. A.4). Additionally, it turned into the first Greenlandic deep ice core to be crystallographically investigated by means of an Automatic Fabric Analyzer (AFA; the first polar ice core to be investigated with this technique was Dome F, cf. 6.2; see also Fig. A.4). Actually, two different AFAs have been used (for a description of the main methods of crystallographic analysis, from the Rigsby stage to modern AFAs, see the review by Wilen et al. 2003): the Japanese model developed by Wang and Azuma (1999) was employed for $c$-axis studies in the depth range 100-2930 m, while grain sizes were investigated between 115 and $880 \mathrm{~m}$ depth with the Australian model developed by Russell-Head and Wilson (2001).

Vertical thin sections for $c$-axis studies were prepared by Wang et al. (2002) at 55-66 m intervals between 100 and $1370 \mathrm{~m}$ depth, and further 300 samples were extracted from the depth range 1370-2930 m. Observed $c$-axis preferred 
orientations were presented in a variety of ways, e.g. as point scatter pole figures, eigenvalues, and statistical measures, viz. degree of orientation, spherical aperture and the Woodcock value (after Woodcock, 1977). Based on these analyses, four crystallographic zones could be identified (cf. Fig. A.2). In Zone 1, ranging from 100 to $750 \mathrm{~m}$ depth, nearly random distributions of $c$-axis orientations are observed. In Zone 2 a broad vertical single maximum develops between 750 and $1300 \mathrm{~m}$ depth. This turns into a vertical girdle distribution in Zone 3, which ranges from 1300 to $2500 \mathrm{~m}$. Finally, a strong vertical single maximum prevails over the girdle below $2500 \mathrm{~m}$. The formation of a vertical girdle distribution of $c$-axes in Zone 3 has been interpreted by Wang et al. (2002) as an evidence for extension flow transverse to the NGRIP ridge, The plane of the vertical girdle lying in the direction of the ridge, perpendicular to the axis of horizontal extension. The change from the girdle to a strong single maximum at about $2500 \mathrm{~m}$ depth suggests the prevalence of simple shear in the lowest part of the ice sheet.

NGRIP Grain sizes have been studied only in the upper $900 \mathrm{~m}$ of the deep ice core, corresponding to approximately the last $5.3 \mathrm{kaBP}$. Svensson et al. (2003b) sampled 15 twin pairs of vertical thin sections evenly distributed in the depth interval 115-880 m, and determined the following parameters for each grain: area, width, height, flattening, roundness and c-axis orientation. In spite of its limited depth range and number of samples, the NGRIP grain size record have become one of the most studied grain size datasets from a Greenlandic deep ice core, owing to its quality and level of detail.

In the general NGRIP grain size analysis, Svensson et al. (2003b) found that the mean cross-sectional area of the grains increases with depth towards a constant value of ca. $10 \mathrm{~mm}^{2}$, and their shape becomes increasingly irregular. The 
grain cross-sectional area distribution develops from a single log-normal to a bimodal log-normal distribution. Owing to this, a standard Normal Grain Growth (NGG) model was not suitable for fitting the entire grain cross-sectional area profile. Instead, an extended, empirical grain growth model was proposed, under the assumption that below a certain depth it was the grain volume rather than the cross-sectional area that grows linearly with time. In a companion paper, Svensson et al. (2003a) investigated the microstructure of a continuous $1.1 \mathrm{~m}$ long section from around $301 \mathrm{~m}$ depth of the NGRIP core with the aim of relating crystallite properties and impurity concentrations. A strong seasonal variation in grain cross-sectional areas was noticed, with the smallest grains appearing in spring, when the concentration of $\mathrm{Ca}^{2+}$ has its maximum, therefore suggesting a relation between grain sizes and dust concentration (according to Whitlow et al., 1992; Legrand and Mayewski, 1997; Kuramoto et al., 2011, the major source of $\mathrm{Ca}^{2+}$ in Greenland is mineral dust, which is transported mainly from Asian sources by turbulent events in early spring). In contrast to grain sizes, lattice orientations did not display a detectable seasonal variation.

The issue of grain growth in the NGRIP core was revisited by Mathiesen et al. (2004), who found that the grain size distributions of all measured depths could be collapsed into a single curve by rescaling. They proposed a modified NGG equation with an additional "grain fragmentation" term (viz. grain splitting via rotation recrystallization; RRX; cf. Appendix A of Part II) and found that the curve that fitted all depths was a steady-state Bessel function, which is significantly different from log-normal distribution previously proposed by Svensson et al. (2003a,b) for the same dataset. Some years later, Durand et al. (2008) complemented the study by Mathiesen et al. (2004) with an investigation of the relation between neighbour- 
ing grains in the NGRIP core. They found evidences that rotation recrystallization (RRX) already occurs in the upper part of the NGRIP core, seemingly at a nearly constant rate, therefore contradicting deformations models (e.g. Montagnat and Duval, 2000) based on the tripartite paradigm (cf. Sect.3.3).

Recently, Roessiger et al. (2011) compared the NGRIP grain size data with the results of grain growth simulations and proved that simple NGG models with an extra grain splitting term may fit well the observed data, but their physical meaning is doubtful. The ice microstructure in the upper hundreds of meters of polar ice sheets is usually not in equilibrium, and this causes noticeable effects on the growth of grains that are only spuriously reproduced by such simplistic models.

\section{News from Antarctica: Vostok, EDC}

Today, Vostok and Dome $\mathrm{C}$ are two of the three sites in Central Antarctica occupied by all-year research stations (the other being the U.S. Amundsen-Scott Station at the Geographic South Pole). Both lie in the Eastern Indian Sector of the Antarctic Ice Sheet, circa $560 \mathrm{~km}$ apart. Deep ice core drilling activities have been occurring in both sites since the early 1970s, in part under the auspices of the International Antarctic Glaciological Project (IAGP), a large program of collaborative glaciological studies involving Australia, France, the United Kingdom, the USA, and the Soviet Union, which was carried on from the late 1960s to the mid 1980s and focused on an extensive part of the East Antarctica (Radok, 1977, 1985; Turchetti et al., 2008). It was only by the turn of the millennium, however, that the respective drilling teams reached terminal depths, with ice older than $400 \mathrm{kaBP}$. 


\subsection{Vostok}

Research at Vostok has a long tradition, which dates back to the setting up of the Soviet Vostok Station in December 1957, during the International Geophysical Year (IGY). Since its its beginning, Vostok has existed as a year-round research base of the Complex Antarctic Expedition (CAE). In 1959 CAE was renamed the Soviet Antarctic Expedition (SAE) and in 1992, after the collapse of the Soviet Union, the Russian Antarctic Expedition (RAE). Beneath Vostok Station and almost $4 \mathrm{~km}$ of ice lies one of the biggest lakes in the world, Lake Vostok, with a surface area larger than $14,000 \mathrm{~km}^{2}$ and a mean water thickness of about $125 \mathrm{~m}$ (Kapitsa et al., 1996).

Deep drilling started at Vostok in April 1970, with Borehole 1, which reached $952.4 \mathrm{~m}$ in May 1972, just before a failure of the winch-brake mechanism that led to the irrecoverable fall of the TELGA-14M electrothermal drill into the hole (Talalay, 2012). After further four boreholes, a number of branch-holes, several drills, and decades of drilling experience, the KEMS-132 electromechanical drill finally reached the transition from meteoric ice into accretion ice (frozen from the beneath subglacial lake) at $3538 \mathrm{~m}$ depth in Borehole 5G-1 (age of meteoric ice estimated to be around $420 \mathrm{kaBP}$, according to Petit et al., 1999). Shortly afterwards, drilling came to a halt in January 1998, at a depth of $3623 \mathrm{~m}$, about $140 \mathrm{~m}$ above the ice-lake interface (Vasiliev et al., 2007).

This episode marked the completion of almost three decades of deep ice coring at Vostok, but it did not establish the end of drilling itself. Somewhat like the building of a Gothic cathedral, drilling at Vostok seemed to be a thrilling, neverending enterprise: after decades of deep ice coring, the main objective of the Vostok program became getting to Lake Vostok, using the existing Borehole 5G 
for access. To this aim, drilling was resumed in 2005 and after all sorts of technical difficulties and the need to open another branch-hole (Borehole 5G-2), lake water was finally hit in February 2012 at 3769.3 m depth (Jones, 2012; Talalay, 2012; Vasiliev et al., 2012).

Originally, the plan was to replace the electromechanical ice-coring drill by a coreless thermal drill at some point close to the ice-water interface (Vasiliev et al., 2011). Eventually, however, no change to thermal drilling was made, and ice-coring continued to the very end (Talalay, 2012; Vasiliev et al., 2012). Contamination of the lake was most likely avoided by a vigorous surge of lake water into the hole as soon as the drill broke into the lake (Vasiliev et al., 2011; Jones, 2012). After raising almost $600 \mathrm{~m}$ into the borehole (equivalent to several cubic metres of subglacial water) the water must have frozen, sealing the lake beneath it (Talalay, 2012). Preliminary results about microbial life in the frozen lake water remain elusive (Schiermeier, 2012, 2013), mainly because of probable contamination of the frozen water by the drilling fluid (a potentially toxic mixture of kerosene and HCFC-141b; Talalay, 2012). Further exploration of the lake using a variety of probes, cameras and water samplers is planned for the coming seasons. Comprehensive crystallographic studies of Vostok ice have been performed in the $2083 \mathrm{~m}$ long core $(\approx 150 \mathrm{kaBP}$ according to Petit et al., 1999) retrieved from Borehole 3G-1 in the period 1980-1982 (Lipenkov et al., 1989; Fig. A.3). Changes in grain size with depth were determined in 110 horizontal thin sections by counting grains within a given area. Grain shapes were estimated by the methods of directed and random secants expressed in terms of the coefficients of planar and linear dimensional orientation (Underwood, 1970). Crystalline $c$-axis orientations were measured with a usual Rigsby universal stage and presented as point 
scatter pole figures.

Lipenkov et al. (1989) found that the mean cross-sectional area of the ice grains experiences a 30 -fold increase with depth down to the interglacial-glacial transition at about $1870 \mathrm{~m}$, followed by a marked $60 \%$ reduction to ca. $12 \mathrm{~mm}^{2}$ within a depth interval of less than $150 \mathrm{~m}$. Grain sizes are systematically smaller in ice from colder periods (which are richer in impurities) than from warmer periods, indicating a correlation between grain size and climate records/impurity concentration. Horizontal grain elongation is noticeable below $100 \mathrm{~m}$ and undergoes a considerable increase between 350 and $500 \mathrm{~m}$ depth. Inspection of thin sections between crossed polarizers suggested the near absence of interpenetrating crystallites and just some indications of undulose extinction below $900 \mathrm{~m}$. These observations led Lipenkov et al. (1989) to assume that the whole core was in the first of the three stages of the tripartite paradigm of polar ice microstructure (cf. Sect. 3.3), namely Normal Grain Growth (NGG) driven by reduction of the grain boundary energy.

Crystallographic analyses revealed a quasi-uniform distribution of $c$-axis orientations in the upper $350 \mathrm{~m}$ of the core, and the gradual formation of a vertical girdle below $454 \mathrm{~m}$ depth. Lipenkov et al. (1989) could identify no significant correlation between $c$-axis preferred orientations and impurity concentration or climate records. On the other hand, the grain elongation along a horizontal direction perpendicular to the plane of the vertical girdle was interpreted as resulting from basal glide induced by a tensile stress in the direction of the elongated grains, so that horizontal simple shearing is probably of little significance along the core and the general ice flow regime above the lake may be comparable to that of ice shelves. 
5.2. $E D C$

The EPICA Dome C (EDC) deep ice core is one of the two sister cores drilled by the European Project for Ice Coring in Antarctica (EPICA), an eleven-year (19962006) joint scientific program of the European Science Foundation (ESF) and the European Commission (EC). A major part of the EPICA funding came from a series of EC projects and from national contributions by ten participating countries (Belgium, Denmark, France, Germany, Italy, The Netherlands, Norway, Sweden, Switzerland, and the United Kingdom). The scientific activities of EPICA were coordinated by a Steering Committee, which included representatives of all ten participating nations (Oerter et al., 2009).

The main objective of EPICA was drilling down to bedrock two ice cores for paleo-climate and -atmosphere records from deep ice of the Antarctic inland. In contrast to its companion EDML core (see Sect. 6.1), the EDC drilling site was chosen due to its remarkably low accumulation rate, which was expected to provide a rather long climate record with very old ice at the bottom of the ice sheet (EPICA community members, 2004). Additionally, the EDC core should yield a long record of the atmospheric influences characteristic of the Indian Sector of Antarctica. A decisive advantage of Dome $\mathrm{C}$ was that its site had already been well studied and documented by numerous field surveys and ice-coring ventures (Lorius et al., 1979; Young, 1979; Duval and Lorius, 1980; Jouzel et al., 1989) executed within the frames of the International Antarctic Glaciological Project (IAGP).

Italy and France provided the logistics for the EDC drilling. In early 2005 the new all-year facility Concordia Station became operational at Dome C, replacing an older French-Italian summer camp on the same site. Drilling started 
in 1996 but the drill got stuck at $788 \mathrm{~m}$ depth and the borehole was abandoned in 1999. This first core has been named EDC96 (EPICA community members, 2004). Drilling of the second core, EDC99 (sometimes also called EDC 2), started in 1999, circa $10 \mathrm{~m}$ apart from the EDC96 borehole. It stopped in December 2004 at a depth of $3260 \mathrm{~m}$, around $15 \mathrm{~m}$ above bedrock (Jouzel et al., 2007), after seismic soundings suggested the presence of melt water just below. Ice at the bottom of the core is estimated to be older than $800 \mathrm{kaBP}$ (Jouzel et al., 2007; Parrenin et al., 2007).

The microstructure of the EDC96 and EDC99 cores have been investigated with several methods, including digital image analyzes of thin sections photographed between crossed polarizers and, similar to NGRIP (cf. Sect. 4.3), two types of $\mathrm{Au}$ tomatic Fabric Analyzers (AFAs): the Japanese model (Wang and Azuma, 1999) and the Australian model (Russell-Head and Wilson, 2001), cf. Fig. A.4.

Wang et al. (2003) studied grain sizes, shapes, and $c$-axis orientations of 33 vertical and horizontal thin sections from 100 to $1500 \mathrm{~m}$ depth of the ice cores EDC96 (100-575 m) and EDC99 (575-1500 m). Grain sizes and $c$-axes were analyzed with the Japanese AFA (Wang and Azuma, 1999), although further information about grain sizes and shapes have also been produced through digital image analyzes of sections photographed between crossed polarizers. In addition, fine microstructure details have been studied in some thick sections using a preliminary version of the automated optical microscopy and image analysis method that would later become known as Microstructure Mapping ( $\mu \mathrm{SM}$; Kipfstuhl et al., 2006, ; cf. Fig. A.4). In another study, Weiss et al. (2002) investigated grain growth in EDC shallow (Holocene) ice through digital image analyzes of ca. 100 vertical thin sections from 100-580 m depth, photographed between crossed po- 
larizers. Following a similar procedure, the EDC99 grain size dataset was later extended by EPICA community members (2004) down to 3139 m with a periodicity of $10 \mathrm{~m}$. All these data have later been complemented by Durand et al. (2009), who studied grain sizes and $c$-axis orientations of the EDC99 ice core in the depth range 214-3133 m using the Australian AFA (Russell-Head and Wilson, 2001). Sampling was performed at $50 \mathrm{~m}$ intervals in the depth ranges $214-313 \mathrm{~m}$ and 511-1500 m (which overlap with the previous study by Wang et al., 2003) and every $11 \mathrm{~m}$ elsewhere.

The outcome of these studies (summarized in Fig. A.3) is that $c$-axis preferred orientations at EDC evolve with depth from a nearly isotropic distribution close to the firn-ice transition at $100 \mathrm{~m}$ to a strong vertical single maximum at the bottom of the core (Wang et al., 2003; Durand et al., 2009). For the upper $1500 \mathrm{~m}$ of EDC, Wang et al. (2003) could show that the gradual clustering of $c$-axes towards the vertical (which is expected for an ice dome undergoing uniaxial compression) agrees well with equivalent datasets from GRIP and Dome F (cf. Sects. 4.1 and 6.2), when plotted together with respect to a common normalized depth (i.e. depth/total ice thickness). Furthermore, a simple model of strain-induced $c$-axis rotation based on the assumption that basal dislocation glide is the dominant deformation mechanism (Azuma, 1994) satisfactorily reproduces the anisotropy evolution with depth in all these cores. Below $1500 \mathrm{~m}$ at EDC, Durand et al. (2009) showed that the more or less steady evolution of $c$-axis preferred orientations becomes punctuated by enhanced clustering of $c$-axes around the vertical, in fine-grained layers with increased impurity concentration. Such a sharp enhancement is particularly noticeable at around $1750 \mathrm{~m}$ depth, which marks the MIS5e-MIS6 transition from the last interglacial to the penultimate glacial period 
(ca. $130 \mathrm{kaBP}$ ). Durand et al. (2009) attributed this enhancement to a combination of several factors: a change in ice rheology (possibly caused by small grain sizes or high impurity concentration), a suitable $c$-axis distribution, and the occurrence of noticeable horizontal simple shearing already at intermediate depths. This combination of factors explains why such an anisotropy enhancement has only been observed at intermediate depths: in shallower EDC ice simple shearing is negligible, while in deeper EDC ice the clustering of $c$-axes is already so strong that further enhancement is no longer noticeable.

Grain size measurements in ice samples from both EDC cores revealed a general grain growth behavior comparable to that observed in the Vostok and Dome F cores (cf. Sects. 5.1 and 6.2): a roughly steady increase of mean grain size with depth (Wang et al., 2003), punctuated by sharp size reductions at critical climatic transitions (Durand et al., 2009). It is suggested that the fine-grained ice observed at such climatic transitions is caused by the pinning of grain boundaries by dust particles, which exist in high concentrations in glacial periods (Weiss et al., 2002; Durand et al., 2009). In EDC Holocene ice the mean grain cross-sectional area doubles with depth, reaching ca. $5 \mathrm{~mm}^{2}$ shortly before the interglacial-glacial transition at about $450 \mathrm{~m}$ depth. At this transition the mean grain size reduces to nearly $3.5 \mathrm{~mm}^{2}$ and remains approximately constant down to $600 \mathrm{~m}$. Below this depth, average grain size starts increasing again up to $50 \mathrm{~mm}^{2}$ at about $1750 \mathrm{~m}$ depth (MIS5e-MIS6 transition), and then drops to half. Below that depth, grains resume growth, but now showing an increasing variability with depth. At the bottom of the core, grains become rather big, reaching several hundreds of $\mathrm{mm}^{2}$ in cross-sectional area.

In the upper $580 \mathrm{~m}$ of the EDC core, Weiss et al. (2002) found that the mean 
grain size data could not be properly fitted with a parabolic Normal Grain Growth (NGG) law. Rather, they proposed a nearly cubic NGG model where the grain volume (instead of its cross-sectional area) increases almost linearly with time. Crystalline misorientation analyzes performed by Durand et al. (2009) with the Australian AFA and by Wang et al. (2003) with optical microscopy revealed evidence for rotation recrystallization $(\mathrm{RRX})$ already at very shallow depths. In particular, Wang et al. (2003) remarked that one out of two grains in the EDC core seemed to have sub-grain boundaries, irrespective of depth.

\section{Recent Antarctic deep ice cores: EDML, Dome F}

Dronning Maud Land (DML) is a large territory in East Antarctica, between $20^{\circ} \mathrm{W}$ and $45^{\circ} \mathrm{E}$. It comprises about one sixth of the Antarctic continent, including the second highest ice dome of the Antarctic ice sheet, Dome F. Two deep ice cores have been retrieved from DML. The first was drilled on Dome F, at the Japanese Dome Fuji Station. The second (EDML) was drilled on an ice ridge stemming from Dome F, at the German Kohnen Station, which lies circa 1000 km northwest from Dome Fuji.

\subsection{EDML}

As already mentioned in Sect. 5.2, the EPICA Dronning Maud Land (EDML) ice core is one of the two sister cores drilled by the European Project of Ice Coring in Antarctica. In contrast to its companion EDC core, the main criteria for choosing the EDML drilling site were (i) a high accumulation rate, which should yield a high temporal resolution of the climate records, and (ii) its location in the Antlantic sector of Antarctica, in central DML, in order to allow direct 
comparison with the climate records of Greenlandic ice cores (EPICA community members, 2006). In contrast to EDC, however, the Central DML region was rather unexplored prior to the EPICA investigations. Therefore, the selection of a precise drilling location required four years (1995-1999) of intensive pre-site surveys. Eventually, the EPICA Steering Committee chose the location for the EDML drilling site and the German Kohnen Station was established there in January 2001. Logistics and drilling were organized by the Alfred Wegener Institute (AWI), Germany. Deep drilling started in EDML in January 2002 using the NGRIP drill apparatus. It finished in January 2006 at $2774 \mathrm{~m}$ depth, nearly $10 \mathrm{~m}$ above bedrock, after subglacial water poured into the borehole (Oerter et al., 2009).

A distinctive feature of the EDML core is that it became the first ice core to have continuous and thorough records of visual stratigraphy and microstructure in microscopic resolution. These records have provided unprecedented details about the mechanics and microstructure of polar ice, as well as their interactions with climate proxies (Faria et al., 2010). A large amount of microstructural features, including grain sizes and shapes, subgrain boundaries, air-bubble sizes, shapes, and counts, slip bands, $c$-axis orientations and cloudy bands (Fig. A.4; see also Part II), have been measured using the automated optical microscopy and image analysis method known as Microstructure Mapping ( $\mu$ SM) (Kipfstuhl et al., 2006), as well as a new version of the Australian Automatic Fabric Analyzer (AFA), model G20 (Wilson et al., 2003). Visual stratigraphy was determined with an automated Icecore Line-Scanner (ILS) similar to the one used at NGRIP (cf. Sect 4.3; Faria et al., 2010, in preparation).

Vertical thick sections of fresh ice and firn were cut at approximately $10 \mathrm{~m}$ in- 
tervals throughout the core (10-2774 $\mathrm{m}$ depth) and prepared for $\mu \mathrm{SM}$ studies using controlled sublimation polishing and etching, as described by Kipfstuhl et al. (2006). In order to minimize relaxation effects, all samples were cut, prepared and mapped in the field, shortly (0-2 days) after drilling. In addition to the standard $\mu \mathrm{SM}$ images, a modified microscopy set-up was used to produce a second series of $\mu \mathrm{SM}$ micrographs highlighting air bubbles of samples from the bubbly-ice zone, viz. 90-1200 m depth (Ueltzhöffer et al., 2010; Bendel et al., 2013). Supplementary vertical thick sections have also been prepared for depths of special interest. Additionally, about 150 vertical and horizontal thin sections from the depth interval 54-2564 $\mathrm{m}$ have been prepared in at least $50 \mathrm{~m}$ increments for AFA analyzes using standard techniques employed in previous ice core studies.

Similar to other Antarctic deep ice cores, the EDML mean grain size has a general tendency to increase with depth (Fig. A.3). However, in the case of EDML the influence of impurities seems more marked. In particular, three periods of pronounced Antarctic cold, known as the Marine Isotope Stages MIS2 (last glacial), MIS4, and MIS6 (penultimate glacial), left their imprints on the EDML microstructure in the form of exceptionally fine-grained ice. In the upper $700 \mathrm{~m}$ of the EDML core, the mean grain cross-sectional area increases with depth from $1.5 \mathrm{~mm}^{2}$ at $100 \mathrm{~m}$ to $4.5 \mathrm{~mm}^{2}$ at about $700 \mathrm{~m}$. Below that depth, which coincides with the interglacial-glacial transition (i.e. MIS1-MIS2 transition, according to the EDML1 chronology; Ruth et al., 2007), mean grain size reduces markedly, reaching ca. $0.8 \mathrm{~mm}^{2}$ at $900 \mathrm{~m}$ depth and remaining small for further $150 \mathrm{~m}$. Grains become bigger again during the warm period of MIS3 and grow in average to more than $6 \mathrm{~mm}^{2}$ at about $1700 \mathrm{~m}$ depth. During the colder period MIS4 (approx. 1700-1850 $\mathrm{m}$ depth), grains get as small as $0.5 \mathrm{~mm}^{2}$ in average, and 
then resume growth reaching an average size around $20 \mathrm{~mm}^{2}$ at $2370 \mathrm{~m}$ depth. Below that point, the most extreme grain-size reduction in EDML takes place, with grains becoming smaller than $0.3 \mathrm{~mm}^{2}$ in average within just some tens of meters. This change coincides with the most striking change in impurity content, caused by the transition from the last interglacial to the penultimate glacial (MIS5e-MIS6 transition, ca. $130 \mathrm{kaBP}$ ). Within the depth range 2385-2405 m the grain boundaries display a characteristic ordered pattern, resembling a "brick wall" (Faria et al., 2006, 2009, in preparation), which offers a patent evidence of strain accommodation by microscopic grain-boundary sliding via microshear (cf. Drury and Humphreys, 1988; Bons and Jessell, 1999). The resulting change in the ice rheology is corroborated by a corresponding change in the visual stratigraphy, characterized by remarkably strong, flat and horizontal cloudy bands, as well as by an abrupt reduction in the borehole diameter by ca. 5\% within a period of less than two years, caused by an accidental lack of drilling-fluid pressure (Faria et al., 2006). Between 2400 and $2500 \mathrm{~m}$ depth, ice remains generally fine-grained, but the grain size variability increases and the visual stratigraphy becomes severely disrupted. Below $2500 \mathrm{~m}$ the ice temperature exceeds $-10^{\circ} \mathrm{C}$ and grain sizes increase dramatically, reaching thousands of $\mathrm{mm}^{2}$ below $2600 \mathrm{~m}$ (Weikusat et al., 2009b).

EDML $c$-axis preferred orientations show the depth evolution typical for an ice ridge (Fig. A.3, cf. Sect. 4.3): an almost uniform distribution in the upper $450 \mathrm{~m}$, followed by the continual development of a great circle girdle distribution down to $1700 \mathrm{~m}$ depth, characteristic of horizontal extension flow transverse to the ridge. Below that depth, a changeover region is formed towards an elongated vertical single maximum, which ends with a sudden collapse of $c$-axes into a strong 
vertical single maximum at $2050 \mathrm{~m}$ depth, where horizontal simple shearing supposedly becomes dominant. Below $2564 \mathrm{~m}$ depth grains become too large for meaningful determination of $c$-axis distributions (Eisen et al., 2007; Faria et al., 2010).

In contrast to the tripartite paradigm invoked to explain the microstructure evolution of certain polar ice cores (e.g. Byrd, GRIP, GISP2; cf. Sects. 3.3, 4.1 and 4.2), dynamic recrystallization is active at all depths in EDML, as confirmed by detailed analyzes of grain shapes, subgrain boundary densities, and neighboring grain misorientations, as well as comparison with microstructures produced in ice creep tests (Hamann et al., 2007; Faria et al., 2009; Weikusat et al., 2009a,b). In fact, dynamic recrystallization markedly affects the ice microstructure already in the firn zone (Kipfstuhl et al., 2009), as it is triggered by the highly heterogeneous deformation of polar ice on the polycrystalline and intracrystalline scales (Faria et al., 2009; cf. Sect. 2.2 of Part II). The complexity of subgrain formation and rotation recrystallization (RRX) has also been exposed by high-resolution lattice orientation analyses via X-ray Laue diffraction (Miyamoto et al., 2011) and Electron Backscatter Diffraction (EBSD; Weikusat et al., 2010): diverse types of subgrain boundaries could be identified, many of them formed by non-basal dislocations. These results show that, while basal dislocations are the main agents of intracrystalline deformation in polar ice, non-basal dislocations play a decisive role in heterogeneous strain accommodation through the formation of subgrain boundaries (Weikusat et al., 2011; cf. Sects. 2.2, 3.3 and 4.1 of Part II).

\subsection{Dome F}

Japanese research in Antarctica has a long tradition that goes back to Nobu Shirase's 1910-1912 expeditions (Shirase, 2011). Modern Japanese Antarctic re- 
search started in conjunction with the International Geophysical Year (IGY, 19571958), through the first Japanese Antarctic Research Expedition (JARE-1) of 1956 (Geographical Survey Institute of Japan, 2007). In 1968, JARE-9 scientists started collecting glaciological, climatological and geochemical data on the ice sheet in East Dronning Maud Land (East DML). These studies were carried on in subsequent JARE expeditions, culminating decades later with the development of the Dome Fuji Ice Coring Project, aiming at a comprehensive study of past and present glaciological/climatological features of the Antarctic ice sheet in the East DML (Dome-F Deep Coring Group, 1998). The Project was planned and executed by JARE, as part of the International Geosphere-Biosphere Program (IGBP) of the International Council for Science (ICSU).

Dome Fuji Station was constructed in 1994 on the summit of East DML (Dome F), the second highest ice dome in Antarctica, $3810 \mathrm{~m}$ above sea level, on a relatively flat bedrock with an elevation of about $800 \mathrm{~m}$. Deep drilling started in August 1995 and reached a depth of 2503 m in December 1996 (Dome-F Deep Coring Group, 1998). Climate records down to this depth seemed intact and the age of the ice was estimated to be around $340 \mathrm{kaBP}$ (Watanabe et al., 1999b; Kawamura et al., 2007).

As reported by Motoyama (2007), drilling stopped temporarily at $2503 \mathrm{~m}$ depth due to a shortage of antifreeze supply, and efforts were made to maintain the borehole open by reaming. During this process, the drill got stuck and the borehole had to be abandoned. Persisting in the aim of full penetration to bedrock, a new deep ice core drilling project commenced at Dome Fuji in 2001. A completely new drill system was developed and drilling started in the austral summer 2003 at the Dome Fuji 2 site, circa 43 m north of the abandoned borehole. In 
January 2007 the JARE team reached the final depth of $3035.2 \mathrm{~m}$, after finding small rocks and signs of frozen subglacial water, both indicating close proximity to the bedrock. A first, preliminary dating suggests that the age of the ice at the bottom of the Dome Fuji 2 core may be around $720 \mathrm{kaBP}$.

Vertical thin sections of the Dome Fuji 1 core were sampled by Azuma et al. (1999) at $20 \mathrm{~m}$ intervals from 100 to $2250 \mathrm{~m}$ depth, and thereafter at $10 \mathrm{~m}$ intervals down to $2503 \mathrm{~m}$. They were prepared for crystallographic analyses following standard techniques employed in previous ice core studies. A major feature of the Dome Fuji 1 core is that it became the first deep ice core to have its $c$-axis orientations, as well as grain sizes and shapes, investigated with an Automatic Fabric Analyzer (AFA), which was developed by Wang and Azuma (1999). The results of these analyses were presented in a variety of ways, including mean grain size, aspect ratio and elongation direction, as well as $c$-axis point scatter pole figures, median inclinations, eigenvalues, mean orientations and misorientation angles.

Azuma et al. (1999, 2000) observed (Fig. A.3) that the mean grain size of Dome Fuji 1 deep ice core is ca. $3 \mathrm{~mm}^{2}$ at $112 \mathrm{~m}$ depth and remains nearly constant down to $420 \mathrm{~m}$ (interglacial-glacial MIS1-MIS2 transition, according to Watanabe et al., 1999a,b). A slight decrease is observed in the depth range 420$700 \mathrm{~m}$ followed by a roughly steady increase in deeper ice, with larger variations, reaching a maximum value of about $83 \mathrm{~mm}^{2}$ at $2490 \mathrm{~m}$. It was found that grain size variations correlate well with the $\delta^{18} \mathrm{O}$ profile (Remark 5), including two conspicuous decreases in mean grain size at about 1830 and $2300 \mathrm{~m}$ depth, which correspond to two interglacial-glacial transitions (MIS5e-MIS6 and MIS7e-MIS8, dated 130 and 245 kaBP, respectively, cf. Watanabe et al., 1999a,b). Grain elon- 
gation is nearly constant with depth down to ca. $800 \mathrm{~m}$, and experiences a slight increase in the mean aspect ratio from 1.7 to 1.9 within the depth range 800$1500 \mathrm{~m}$. Below that depth range, the aspect ratio fluctuates markedly $( \pm 10 \%)$ about 1.9. No signs of nucleation recrystallization (SIBM-N; cf. Appendix A of Part II) could be identified down to $2500 \mathrm{~m}$.

Remark 5. The oxygen isotope ratio $\delta^{18} \mathrm{O}$ is commonly used as a proxy for paleotemperature. Experience shows that in Antarctic ice cores the inverted $\delta^{18} \mathrm{O}$ depth profile correlates with the concentrations of most impurities, in such a way that impurity concentration is generally higher (and $\delta^{18} \mathrm{O}$ values lower) in colder periods (EPICA community members, 2006; Faria et al., 2010).

As expected for an ice dome, crystallographic $c$-axis orientations gradually change with depth from a random orientation distribution pattern near the surface to a strong vertical single maximum at $2500 \mathrm{~m}$ depth. Curiously, Azuma et al. $(1999,2000)$ found that the clustering of $c$-axes tends to be weaker at depths with high impurity concentration and small grain sizes, a result that is not incompatible with the observations from Dye 3 and GRIP cores (Sects. 3.4 and 4.1), but stays in direct contrast to the results from Camp Century, Byrd and GISP2 cores (cf. Sects. 3.2, 3.3 and 4.2). A possible explanation of this phenomenon has been put forward by Azuma et al. $(1999,2000)$ : they propose that diffusion creep could sometimes become significant in polar ice under conditions of low temperature and low deviatoric stress, provided that the impurity concentration is high enough and the mean grain size sufficiently small, as it happens in the high-impurity layers of the Dome Fuji core. 


\section{Conclusion and afterword}

Compared to glaciers and other natural ice bodies, polar ice sheets offer many advantages for the study of natural ice microstructure evolution. In particular, the history of stress and temperature conditions experienced by a piece of polar ice is generally much longer, simpler and more steady than it would be in a glacier. This facilitates considerably the interpretation of deformation and recrystallization microstructures. Therefore, polar ice cores have become invaluable for investigations of the microstructure evolution of natural ice.

In spite of all these advantages, it becomes evident from this review that understanding the microstructural evolution of polar ice has been a challenging task for many decades. Even today, our knowledge about this subject is still imperfect and incomplete, as discussed in detail in the companion Part II of this work (Faria et al., this issue). The conclusions drawn from the analyses of different ice cores have not always been consonant, as summarized in Table B.2. Such a difficulty can be attributed to several causes, ranging from the high variability of natural phenomena and the occasional subjectivity of certain methods (as revealed by the grain size studies by Gow et al., 1997 and Kipfstuhl et al., 2009) to the fact that most deep ice cores retrieved in the last decades are climate-motivated cores, meaning that they are generally extracted from rather singular sites (e.g. domes or ridges) that provide best-quality paleoclimate records, but rather unrepresentative (and sometimes even pathological) physical data.

These facts give support to the thesis, which is being endorsed by an increasing number of glaciologists, that further progress in ice-core physics demands the production of physically motivated deep ice cores (Faria, 2009), viz. cores extracted from sites that are representative of the most common physical processes taking 
place in polar ice sheets (e.g. flow instabilities, changes in ice rheology, subglacial processes, etc.). To achieve this aim, multidisciplinary collaborations are essential (like those promoted by the ESF Research Networking Programme MicroDynamics of Ice, Micro-DICE). By joining forces with geologists, geophysicists and other Earth and engineering scientists, glaciologists may have much stronger arguments to convince funding agencies and policy makers of the necessity of an international and multidisciplinary drilling program for physically motivated deep ice cores. Such a program would not only generate invaluable results for ice physics, geology and materials science: it would also provide the basis for prodigious advances in the study of palaeoclimate records of climate-motivated ice cores.

Afterword. During the preparation of this manuscript we received with great sadness the news on the passing of our colleague and friend Sigfús Jóhann Johnsen (1940-2013), to whom we dedicate this work. Sigfús played a fundamental role in, and made great contributions to, all Greenland deep ice core drillings (since Dye 3) and many ice-core studies (since Camp Century). He was a leading name in the development of deep ice core drilling in Greenland and Antarctica, participating in 36 ice coring expeditions onto the Greenland ice sheet as "drill-master" and scientific expert (IGS, 2013). We have learned the art of deep ice coring from him and have applied this knowledge in uncountable ice-core projects. Sigfús never retired. He tried to go onto the Greenland ice sheet to perform drilling and research even after having been advised not to do so, because of his debilitated health. He was a dedicated ice core scientist and a truly hero of glaciology. We all miss his charismatic personality, which has been cherished in all corners of the world. 


\section{Acknowledgements}

The authors would like to thank Daniel Koehn (Special Issue Editor), Jens Roessiger and an anonymous reviewer for insightful revisions, as well as Tim Horscroft (Review Papers Coordinator) and Joao Hipertt (Editor) for managing the submission and publication process. Thanks go also to Daniela Jansen for useful suggestions and the production of the KML file of ice-core sites (available on-line), and also to Christian Weikusat for his help with the preparation of several figures. Support from ESF Research Networking Programme Micro-Dynamics of Ice (Micro-DICE) is gratefully acknowledged. IW acknowledges also financial support by the German Research Foundation (HA 5675/1-1, WE 4695/1-2) via SPP 1158 and by the Helmholtz Association (VH-NG-802).

\section{References}

Achermann, D., 2009. Die Schnee- und Lawinenforschung in der Schweiz. Ph.D. thesis, University of Zurich, Zurich.

Adams, F. D., 1990. The Birth and Development of the Geological Sciences. Dover, New York, originally published by Williams \& Wilkins, Baltimore, 1938.

Ahlmann, H. W., Droessler, E. G., 1949. Glacier ice crystal measurements at Kebnekajse, Sweden. J. Glaciol. 1 (5), 269-274.

Alley, R. B., Gow, A. J., Meese, D. A., 1995. Mapping c-axis fabrics to study physical processes in ice. J. Glaciol. 41 (137), 197-203. 
Alley, R. B., Gow, A. J., Meese, D. A., Fitzpatrick, J. J., Waddington, E. D., Bolzan, J. F., 1997. Grain-scale processes, folding, and stratigraphic disturbance in the Greenland Ice Sheet Project 2 ice core. J. Geophys. Res. 102, 26819-26830.

Alley, R. B., Woods, G. A., 1996. Impurity influence on normal grain growth in the GISP2 ice core, greenland. J. Glaciol. 42 (141), 255-260.

Augustin, L., Panichi, S., Frascati, F., 2007. EPICA Dome C 2 drilling operations: performances, difficulties, results. Ann. Glaciol. 47, 68-72.

Azuma, N., 1994. A flow law for anisotropic ice and its application to ice sheets. Earth Planet. Sci. Lett. 128, 601-614.

Azuma, N., Wang, Y., Mori, K., Narita, H., Hondoh, T., Shoji, H., Watanabe, O., 1999. Textures and fabrics in the Dome F (Antarctica) ice core. Ann. Glaciol. 29, 163-168.

Azuma, N., Wang, Y., Yoshida, Y., Narita, H., Hondoh, T., Shoji, H., Watanabe, O., 2000. Crystallographic analysis of the Dome Fuji ice core. In: Hondoh, T. (Ed.), Physics of Ice Core Records. Hokkaido University Press, Sapporo, pp. $45-61$.

Bader, H., 1951. Introduction to ice petrofabrics. J. Geol. 59 (6), 519-536.

Bader, H., 1962. Scope, problems, and potential value of deep core drilling in ice sheets. Special Report 58, U.S. Army Cold Regions Research and Engineering Laboratory, Hanover, NH. 
Bader, H., Haefeli, R., Bucher, E., Neher, J., Eckel, O., Thams, C., 1939. Der Schnee und seine Metamorphose. Vol. 3 of Beiträge zur Geologie der Schweiz - Geotechnische Serie - Hydrologie. Kümmerly and Frey, Bern.

Bell, R. E., Studinger, M., Tikku, A. A., Clarke, G. K. C., Gutner, M. M., Meertens, C., 2002. Origin and fate of Lake Vostok water frozen to the base of the East Antarctic ice sheet. Nature 416, 307-310.

Bendel, V., Ueltzhöffer, K. J., Freitag, J., Kipfstuhl, S., Kuhs, W. F., Garbe, C. S., Faria, S. H., 2013. High-resolution variations in size, number, and arrangement of air bubbles in the EPICA DML ice core. J. Glaciol. 59 (217), 972-980.

Bentley, C. R., Koci, B. R., 2007. Drilling to the beds of the Greenland and Antarctic ice sheets: a review. Ann. Glaciol. 47, 1-9.

Bernal, J. D., Fowler, R. H., 1933. A theory of water and ionic solution, with particular reference to hydrogen and hydroxyl ions. J. Chem. Phys., 515-548.

Bons, P. D., Jessell, M. W., 1999. Micro-shear zones in experimentally deformed octachloropropane. J. Struct. Geol. 21, 323-334.

Bowden, F. P., 1953. Friction on snow and ice. Proc. Roy. Soc. London A 217, $462-478$.

Bowden, F. P., Hughes, T. P., 1939. The mechanism of sliding on ice and snow. Proc. Roy. Soc. London A 172, 280-298.

Clarke, G. K. C., 1987. A short history of scientific investigations on glaciers. J. Glaciol. Special Issue, 4-24. 
Clarke, G. K. C., 2005. Subglacial processes. Annu. Rev. Earth Planet Sci. 33, 247-276.

Dahl-Jensen, D., Gundestrup, N., Gogineni, S. P., Miller, H., 2003. Basal melt at NorthGRIP modeled from borehole, ice-core and radio-echo sounder observations. Ann. Glaciol. 37, 207-212.

Dahl-Jensen, D., Gundestrup, N. S., August 1987. Constitutive properties of ice at Dye3, Greenland. In: Waddington, E. D., Walder, J. S. (Eds.), The physical basis of ice sheet modelling. No. 170 in IAHS Publication. pp. 31-43.

Dahl-Jensen, D., Gundestrup, N. S., Keller, K., Johnsen, S. J., Gogineni, S. P., Allen, G. T., Chuah, T. S., Miller, H., Kipfstuhl, S., Waddington, E. D., 1997. A search in north Greenland for a new ice-core drill site. J. Glaciol. 43 (144), 300-306.

Dahl-Jensen, D., Gundestrup, N. S., Miller, H., Watanabe, O., Johnsen, S. J., Steffensen, J. P., Clausen, H. B., Svensson, A., Larsen, L. B., 2002. The NorthGRIP deep drilling programme. Ann. Glaciol. 35, 1-4.

Dansgaard, W., 2004. Frozen Annals: Greenland Ice Cap Research. Narayana Press, Odder, Denmark.

Dansgaard, W., Clausen, H. B., Gundestrup, N. S., Hammer, C. U., Johnsen, S. J., Hvidberg, C. S., Steffensen, J. P., Kristinsdottir, P. M., Reeh, N., 1982. A new Greenland deep ice core. Science 218 (4579), 1273-1277.

Dansgaard, W., Johnsen, S. J., 1969. A flow model and time scale for the ice core from Camp Century, Greenland. J. Glaciol. 8 (53), 215-223. 
Dansgaard, W., Johnsen, S. J., Clausen, H. B., Dahl-Jensen, D., Gundestrup, N. S., Hammer, C. U., Hvidberg, C. S., Steffensen, J. P., Sveinbjornsdottir, A. E., Jouzel, J., Bond, G., 1993. Evidence for general instability of past climate from a 250-kyr ice-core record. Nature 364, 218-220.

Dansgaard, W., Johnsen, S. J., Møller, J., Langway, Jr., C. C., 1969. One thousand centuries of climatic record from Camp Century on the Greenland ice sheet. Science 166 (3903), 377-381.

De la Chapelle, S., Castelnau, O., Lipenkov, V., Duval, P., 1998. Dynamic recrystallization and texture development in ice as revealed by the study of deep ice cores in antarctica and greenland. J. Geophys. Res. 103, 5091-5105.

de Quervain, M., Röthlisberger, H., 1999. Henri bader (1907-1998). ICE News Bull. Int. Glaciol. Soc. 120 (2), 20-22.

Dome-F Deep Coring Group, 1998. Deep ice core drilling at Dome Fuji and glaciological studies in East Dronning Maud Land, Antarctica. Ann. Glaciol. $27,333-337$.

Drury, M. R., Humphreys, F. J., 1988. Microstructural shear criteria associated with grain-boundary sliding during ductile deformation. J. Struct. Geol. 10, 8389.

Durand, G., Persson, A., Samyn, D., Svensson, A., 2008. Relation between neighbouring grains in the upper part of the NorthGRIP ice core: implications for rotation recrystallization. Earth Planet. Sci. Lett. 265 (3), 666-671.

Durand, G., Svensson, A., Persson, A., Gagliardini, O., Gillet-Chaulet, F., Sjolte, 
J., Montagnat, M., Dahl-Jensen, D., 2009. Evolution of the texture along the EPICA Dome C Ice Core. Low Temp. Sci. 68, 91-105.

Durham, W. B., Stern, L. A., Kirby, S. H., 2001. Rheology of ice I at low stress and elevated confining pressure. J. Geophys. Res. 106 (6), 11031-11042.

Duval, P., Ashby, M. F., Anderman, I., 1983. Rate-controlling processes in the creep of polycrystalline ice. J. Phys. Chem. 87, 4066-4074.

Duval, P., Lorius, C., 1980. Crystal size and climatic record down to the last ice age from Antarctic ice. Earth Planet. Sci. Lett. 48 (1), 59-64.

Eisen, O., Hamann, I., Kipfstuhl, S., Steinhage, D., Wilhelms, F., 2007. Direct evidence for radar reflector originating from changes in crystal-orientation fabric. The Cryosphere 1, 1-10.

EPICA community members, 2004. Eight glacial cycles from an Antarctic ice core. Nature 429 (6992), 623-628.

EPICA community members, 2006. One-to-one coupling of glacial climate variability in Greenland and Antarctica. Nature 444 (7116), 195-197.

Evatt, G. W., Fowler, A. C., Clark, C. D., Hulton, N. R. J., 2006. Subglacial floods beneath ice sheets. Phil. Trans. R. Soc. London A 364, 1769-1794.

Faria, S. H., 2009. The multidisciplinary ice core. Low Temp. Sci. 68, 35-37.

Faria, S. H., Freitag, J., Kipfstuhl, S., 2010. Polar ice structure and the integrity of ice-core paleoclimate records. Quat. Sci. Rev. 29 (1), 338-351. 
Faria, S. H., Hamann, I., Kipfstuhl, S., Miller, H., 2006. Is Antarctica like a birthday cake? Preprint 33/2006, Max Planck Institute for Mathematics in the Sciences, Leipzig.

Faria, S. H., Hutter, K., 2001. The challenge of polycrystalline ice dynamics. In: Kim, S., Jung, D. (Eds.), Advances in Thermal Engineering and Sciences for Cold Regions. Society of Air-Conditioning and Refrigerating Engineers of Korea (SAREK), Seoul, pp. 3-31.

Faria, S. H., Kipfstuhl, S., Azuma, N., Freitag, J., Hamann, I., Murshed, M. M., Kuhs, W. F., 2009. The multiscale structure of Antarctica. Part I: inland ice. Low Temp. Sci. 68, 39-59.

Faria, S. H., Kipfstuhl, S., Lambrecht, A., in preparation. The EPICA-DML deep ice core. Springer, Heidelberg.

Faria, S. H., Weikusat, I., Azuma, N., this issue. The microstructure of polar ice. Part II: state of the art. J. Struct. Geol.

Fristrup, B., 1959. Recent investigations of the Greenland Ice Cap. Geografisk Tidsskrift 58, 1-29.

Geographical Survey Institute of Japan, 2007. 50 years of Antarctic research expeditions by the Geographical Survey Institute. Bull. Geogr. Survey Inst. 54, $1-24$.

Glen, J. W., 1952. Experiments on the deformation of ice. J. Glaciol. 2 (12), 111114. 
Glen, J. W., 1955. The creep of polycrystalline ice. Proc. Roy. Soc. London A 228, 519-538.

Gow, A. J., 1963a. The inner structure of the Ross Ice Shelf at Little America V, Antarctica, as revealed by deep core drilling. In: IAHS Red Book 61. International Association of Hydrological Sciences, pp. 272-274.

Gow, A. J., 1963b. Results of measurements in the 309 meter bore hole at Byrd Station, Antarctica. J. Glaciol. 4 (36), 771-784.

Gow, A. J., 1968. Deep core studies of the accumulation and densification of snow at Byrd Station and Little America V, Antarctica. Research Report 197, U. S. Army CRREL, Hanover, NH.

Gow, A. J., 1969. On the rates of growth of grains and crystals in south polar firn. J. Glaciol. 8 (53), 241-252.

Gow, A. J., Meese, D., 2007. Physical properties, crystalline textures and c-axis fabrics of the Siple dome (Antarctica) ice core. J. Glaciol. 53 (183), 573-584.

Gow, A. J., Meese, D. A., Alley, R. B., Fitzpatrick, J. J., Anandakrishnan, S., Woods, G. A., Elder, B. C., 1997. Physical and structural properties of the Greenland Ice Sheet Project 2 ice core: a review. J. Geophys. Res. 102, 26559_ 26575.

Gow, A. J., Williamson, T., 1976. Rheological implications of the internal structure and crystal fabrics of the West Antarctic ice sheet as revealed by deep core drilling at Byrd Station. Geol. Soc. Am. Bull. 87, 1665-1677. 
GRIP community members, 1996. Greenland Ice Core Project: An ESF Research Programme. Final report. Tech. rep., European Science Foundation, Strasbourg.

Gundestrup, N. S., Hansen, B. L., 1984. Bore-hole survey at Dye 3, south Greenland. J. Galciol. 30, 282-288.

Haefeli, R., von Sury, H., 1975. Strain and stress in snow, firn and ice along the EGIG profile of the Greenland ice sheet. In: IAHS Red Book 114. International Association of Hydrological Sciences, pp. 342-352.

Hamann, I., Weikusat, C., Azuma, N., Kipfstuhl, S., May 2007. Evolution of ice crystal microstructures during creep experiments. J. Glaciol. 53 (182), 479-489.

Hammer, C. U., Clausen, H. B., Langway, Jr., C. C., 1994. Electrical conductivity method (ECM) stratigraphic dating of the Byrd Station ice core, Antarctica. Ann. Glaciol. 20, 115-120.

Hansen, B. L., Langway, Jr., C. C., 1966. Deep core drilling and core analysis at Camp Century, Greenland, 1961-1966. Antarct. J. U.S. 1 (5), 207-208.

Herron, S. L., Langway, Jr., C. C., 1979. The debris-laden ice at the bottom of the Greenland Ice Sheet. J. Glaciol. 23 (89), 193-207.

Herron, S. L., Langway, Jr., C. C., 1982. A comparison of ice fabrics and textures at Camp Century, Greenland and Byrd Station, Antarctica. Ann. Glaciol. 3, $118-124$.

Herron, S. L., Langway, Jr., C. C., Brugger, K. A., 1985. Ultrasonic velocities and crystalline anisotropy in the ice core from Dye 3, Greenland. In: Langway, Jr., C. C., Oeschger, H., Dansgaard, W. (Eds.), Greenland Ice Core: Geophysics, 
Geochemistry, and the Environment. Vol. 33 of Geophys. Monograph. American Geophysical Union, Washington, DC, pp. 23-31.

Hobbs, P. V., 1974. Ice Physics. Clarendon, Oxford.

Holtzscherer, J. J., de Q. Robin, G., Glen, J. W., 1954. Depth of polar ice caps. Geogr. J. 120 (2), 193-202.

Hughes, T. P., Seligman, G., 1939a. The bearing of snow permeability and retentivity on the density increase of firn and ice-band formation in glaciers. In: IAHS Red Book 26, Commission of Snow and Glaciers, Q1-R3. International Association of Hydrological Sciences, pp. 1-7.

Hughes, T. P., Seligman, G., 1939b. The temperature, melt water movement and density increase in the névé of an Alpine glacier. Mon. Not. R. Astron. Soc., Geophys. Suppl. 4, 615-647.

Hvidberg, C. S., Keller, K., Gundestrup, N. S., Tscheming, C. C., Forsberg, R., 1997. Mass balance and surface movement of the Greenland Ice Sheet at Summit, Central Greenland. Geophys. Res. Lett. 24 (18), 2307-2310.

IGS, June 2013. Sigfús Jóhann Johnsen 1940-2013. http://http://www. igsoc .org/news/sigfusjohnsen/, retrieved on 01 Sep 2013.

Johnsen, S. J., Dahl-Jensen, D., Dansgaard, W., Gundestrup, N. S., 1995. Greenland palaeotemperatures derived from GRIP bore hole temperaure and ice core isotope profiles. Tellus 47B, 624-629.

Johnsen, S. J., Gundestrup, N. S., Hansen, S. B., Schwander, J., Rufli, H., 1994. 
The new improved version of the ISTUK ice core drill. Mem. Natl. Inst. Polar Res., Spec. Issue 49, 9-23.

Jones, N., 2012. Russians celebrate Vostok victory. Nature 482 (7385), 287.

Jouzel, J., Masson-Delmotte, V., Cattani, O., Dreyfus, G., Falourd, S., Hoffmann, G., Minster, B., Nouet, J., Barnola, J. M., Chappellaz, J., Fischer, H., Gallet, J. C., Johnsen, S., Leuenberger, M., Loulergue, L., Luethi, D., Oerter, H., Parrenin, F., Raisbeck, G., Raynaud, D., Schilt, A., Schwander, J., Selmo, E., Souchez, R., Spahni, R., Stauffer, B., Stenni, J. P. S. B., Stocker, T. F., Tison, J. L., Werner, M., Wolff, E. W., 2007. Orbital and millennial Antarctic climate variability over the past 800,000 years. Science 317 (5839), 793-797.

Jouzel, J., Raisbeck, G., Benoist, J. P., Yiou, F., Lorius, C., Raynaud, D., Petit, J. R., Barkov, N. I., Korotkevitch, Y. S., Kotlyakov, V. M., 1989. A comparison of deep Antarctic ice cores and their implications for climate between 65,000 and 15,000 years ago. Quat. Res. 31 (2), 135-150.

Kapitsa, A. P., Ridley, J. K., Robin, G. D. Q., Siegert, M. J., Zotikov, I. A., 1996. A large deep freshwater lake beneath the ice of central East Antarctica. Nature 381 (6584), 684-686.

Kawamura, K., Parrenin, F., Lisiecki, L., Uemura, R., Vimeux, F., Severinghaus, J. P., Hutterli, M. A., Nakazawa, T., Aoki, S., Jouzel, J., Raymo, M. E., Matsumoto, K., Nakata, H., Motoyama, H., Fujita, S., Goto-Azuma, K., Fujii, Y., Watanabe, O., 2007. Northern Hemisphere forcing of climatic cycles in Antarctica over the past 360000 years. Nature 448, 912-916. 
Kipfstuhl, S., Faria, S. H., Azuma, N., Freitag, J., Hamann, I., Kaufmann, P., Miller, H., Weiler, K., Wilhelms, F., 2009. Evidence of dynamic recrystallization in polar firn. J. Geophys. Res. 114, B05204.

Kipfstuhl, S., Hamann, I., Lambrecht, A., Freitag, J., Faria, S. H., Grigoriev, D., Azuma, N., 2006. Microstructure mapping: A new method for imaging deformation-induced microstructural features of ice on the grain scale. J. Glaciol. 52 (178), 398-406.

Kuramoto, T., Goto-Azuma, K., Hirabayashi, M., Miyake, T., Motoyama, H., Dahl-Jensen, D., Steffensen, J. P., 2011. Seasonal variations of snow chemistry at NEEM, Greenland. Ann, Glaciol. 52 (58), 193-200.

Landais, A., Chappellaz, J., Delmotte, M., Jouzel, J., Blunier, T., Bourg, C., Caillon, N., Cherrier, S., Malaizé, B., Masson-Delmotte, V., Raynaud, D., Schwander, J., Steffensen, J. P., 2003. A tentative reconstruction of the last interglacial and glacial inception in Greenland based on new gas measurements in the Greenland Ice Core Project (GRIP) ice core. J. Geophys. Res. 108 (D18), 4563.

Lange, M. A., 1988. A computer-controlled system for ice-fabric analysis on a Rigsby stage. Ann, Glaciol. 10, 92-94.

Langway, Jr., C. C., 1970. Stratigraphic analysis of a deep ice core from Greenland. Special Paper 125, Geological Society of America, Boulder, CO.

Langway, Jr., C. C., 2008. The history of early polar ice cores. Technical Report ERDC/CRREL TR-08-1, U.S. Army Engineer Research and Development Center, Cold Regions Research and Engineering Laboratory, Hanover, NH. 
Langway, Jr., C. C., Shoji, H., Azuma, N., 1988. Crystal size and orientation patterns in the Wisconsin-age ice from Dye 3, Greenland. Ann, Glaciol. 10, $109-115$.

Legrand, M., Mayewski, P. A., 1997. Glaciochemistry of polar ice cores: a review. Rev. Geophys. 35, 219-143.

Lemke, P., Ren, J., Alley, R. B., Allison, I., Carrasco, J., Flato, G., Fujii, Y., Kaser, G., Mote, P., Thomas, R. H., Zhang, T., 2007. Observations: changes in snow, ice and frozen ground. In: Solomon, S., Qin, D., Manning, M., Chen, Z., Marquis, M., Averyt, K. B., Tignor, M., Miller, H. L. (Eds.), Climate Change 2007: The Physical Science Basis. Contribution of Working Group I to the Fourth Assessment Report of the Intergovernmental Panel on Climate Change (IPCC). Cambridge University Press, Cambridge.

Lhomme, N., Clarke, G. K. C., Marshall, S. J., 2005. Tracer transport in the Greenland Ice Sheet: constraints on ice cores and glacial history. Quat. Sci. Rev. 24, 173-194.

Lipenkov, V. Y., Barkov, N. I., Duval, P., Pimienta, P., 1989. Crystalline texture of the $2083 \mathrm{~m}$ ice core at vostok station, antarctica. J. Glaciol. 35 (121), 392-398.

Lorius, C., Merlivat, L., Jouzel, J., Pourchet, M., 1979. A 30,000-yr isotope climatic record from Antarctic ice. Nature 280 (5724), 644-648.

Lythe, M. B., Vaughan, D. G., 2001. BEDMAP: a new ice thickness and subglacial topographic model of Antarctica. J. Geophys. Res. 106 (B6), 11335-11351. 
Mathiesen, J., Ferkinghoff-Borg, J., Jensen, M. H., Levinsen, M., Olesen, P., DahlJensen, D., Svensson, A., 2004. Dynamics of crystal formation in the Greenland NorthGRIPice core. J. Glaciol. 50 (170), 325-328.

Meese, D. A., Gow, A. J., Alley, R. B., Zielinski, G. A., Grootes, P. M., Ram, M., Taylor, K. C., Mayewski, P. A., Bolzan, J. F., 1997. The Greenland Ice Sheet Project 2 depth-age scale: methods and results. J. Geophys. Res. 102, 26411-26423.

Merlivat, L., Ravoire, J., Vergnaud, J. P., Lorius, C., 1973. Tritium and deuterium content of the snow in Groenland. Earth Planet. Sci. Lett. 19 (2), 235-240.

Miller, M. M., 1954. Juneau Icefield Research Program. Juneau Icefield Research Program Report 7, American Geographic Society.

Mills, W. J., 2003. Exploring Polar Frontiers. Vol. 1. ABC-CLIO, Santa Barbara, CA.

Miyamoto, A., Weikusat, I., Hondoh, T., 2011. Complete determination of ice crystal orientation and microstructure investigation on ice core samples enabled by a new x-ray laue diffraction method. J. Glaciol. 57 (201), 67-74, awin18929.

Montagnat, M., Duval, P., 2000. Rate controlling processes in the creep of polar ice, influence of grain boundary migration associated with recrystallization. Earth Planet. Sci. Lett. 183, 179-186.

Motoyama, H., 2007. The second deep ice coring project at Dome Fuji, Antarctica. Sci. Drilling 5, 41-43. 
Motoyama, H., Furukawa, T., Nishio, F., 2008. Study of ice flow observations in Shirase drainage basin and around Dome Fuji area, East Antarctica by differential GPS method. Nankyoku Shiryo (Antarctic Record) 52, 216-231, (in Japanese).

Nolan, M., Motkya, R. J., Echelmeyer, K., Trabant, D. C., 1995. Ice-thickness measurements of Taku Glacier, Alaska, U.S.A., and their relevance to its recent behavior. J. Glaciol. 41 (139), 541-553.

NorthGRIP members, 2004. High-resolution record of the Northern Hemisphere climate extending into the last interglacial period. Nature 431, 147-151.

Obbard, R., Baker, I., 2007. The microstructure of meteoric ice from Vostok, Antarctica. J. Glaciol. 53 (180), 41-62.

Oerter, H., Drücker, C., Kipfstuhl, S., Wilhelms, F., 2009. Kohnen station, the drilling camp for the EPICA deep ice core in Dronning Maud Land. Polarforschung $78(1 / 2), 1-23$.

Parrenin, F., Barnola, J.-M., Beer, J., Blunier, T., Castellano, E., Chappellaz, J., Dreyfus, G., Fischer, H., Fujita, S., Jouzel, J., Kawamura, K., Lemieux-Dudon, B., Loulergue, L., Masson-Delmotte, V., Narcisi, B., Petit, J.-R., Raisbeck, G., Raynaud, D., Ruth, U., Schwander, J., Severi, M., Spahni, R., Steffensen, J. P., Svensson, A., Udisti, R., Waelbroeck, C., Wolff, E., 2007. The EDC3 chronology for the EPICA Dome C ice core. Clim. Past 3, 485-497.

Paterson, W. S. B., 1983. Deformation within polar ice sheets: an analysis of the Byrd Station and Camp Century borehole-tilting measurements. Cold Reg. Sci. Technol. 8 (2), 165-179. 
Paterson, W. S. B., 1991. Why ice-age ice is sometimes "soft". Cold Reg. Sci. Technol. 20 (1), 75-98.

Peel, D. A., 1995. Profiles of the past. Nature 378, 234-235.

Pelto, M. S., Miller, M. M., 1990. Mass balance of the Taku Glacier, Alaska from 1946-1986. Northw. Sci. 64, 121-130.

Perutz, M. F., 1948. A description of the iceberg aircraft carrier and the bearing of the mechanical properties of frozen wood pulp upon some problems of glacier flow. J. Glaciol. 1 (3), 95-104.

Perutz, M. F., 1949. The flow of ice and other solids. in: Joint meeting of the british glaciological society, the british rheologists' club and the institute of metals. J. Glaciol. 1 (5), 231-240.

Perutz, M. F., 1950a. Direct measurement of the velocity distribution in a vertical profile through a glacier. J. Glaciol. 1 (7), 382-383.

Perutz, M. F., 1950b. In: Glaciology-the flow of glaciers. The Observatory $70(855), 64-65$.

Perutz, M. F., 1953. The flow of glaciers. Nature 172 (4386), 929-932.

Perutz, M. F., Seligman, G., 1939. A crystallographic investigation of glacier structure and the mechanism of glacier flow. Proc. Roy. Soc. London A 172, $335-360$.

Petit, J. R., Jouzel, J., Raynaud, D., Barkov, N. I., Barnola, J.-M., Basile, I., Bender, M., Chappellaz, J., Davisk, M., Delaygue, G., Delmotte, M., Kotlyakov, 
V. M., Legrand, M., Lipenkov, V. Y., Lorius, C., Pépin, L., Ritz, C., Saltzman, E., Stievenard, M., 1999. Climate and atmospheric history of the past 420,000 years from the Vostok ice core, Antarctica. Nature 399, 429-436.

Petrenko, V. F., Whitworth, R. W., 1999. Physics of Ice. Oxford University Press, Oxford.

Radok, U., 1977. International Antarctic Glaciological Project: past and future. Antarct. J. U.S. 12 (1), 32-38.

Radok, U., 1985. The Antarctic ice. Sci. Amer. 253 (2), 98-105.

Reeh, N., 1989. The age-depth profile in the upper part of a steady-state ice sheet. J. Glaciol. 35 (121), 406-417.

Reeh, N., Clausen, H. B., Dansgaard, W., Gundestrup, N., Hammer, C. U., Johnsen, S. J., 1978. Secular trends of accumulation rates at three Greenland stations. J. Glaciol. 20 (82), 27-30.

Rignot, E., Mouginot, J., Scheuchl, B., 2011. MEaSUREs InSAR-based Antarctica ice velocity map. version 1 .

Rigsby, G. P., 1951. Crystal fabric studies on Emmons Glacier Mount Rainier, Washington. J. Geol. 59 (6), 590-598.

Rigsby, G. P., 1958. Fabrics of glacier and laboratory deformed ice. In: IAHS Red Book 47, Physics of the Movement of Ice. International Association of Hydrological Sciences, pp. 351-358.

Rigsby, G. P., 1960. Crystal orientation in glacier and in experimentally deformed ice. J. Glaciol. 3 (27), 589-606. 
Ritz, C., 1989. Interpretation of the temperature profile measured at Vostok, East Antarctica. Ann. Glaciol. 12, 138-144.

Robin, G. D. Q., 1955. Ice movement and temperature distribution in glaciers and ice sheets. J. Glaciol. 18 (18), 523-532.

Roessiger, J., Bons, P. D., Griera, A., Jessell, M. W., Evans, L., Montagnat, M., Kipfstuhl, S., Faria, S. H., Weikusat, I., 2011. Competition between grain growth and grain-size reduction in polar ice. J. Glaciol. 57 (205), 942-948.

Russell-Head, D. S., Wilson, C. J. L., 2001. Automated fabric analyzer system for quartz and ice. Geol. Soc. Aust. Abstracts 64, 159.

Ruth, U., Barnola, J. M., Beer, J., Bigler, M., Blunier, T., Castellano, E., Fischer, H., Fundel, F., Huybrechts, P., Kaufmann, P., Kipfstuhl, S., Lambrecht, A., Morganti, A., Oerter, H., Parrenin, F., Rybak, O., Severi, M., Udisti, R., Wilhelms, F., Wolff, E., 2007. "EDML1": a chronology for the EPICA deep ice core from Dronning Maud Land, Antarctica, over the last 150000 years. Clim. Past 3, 475-484.

Schiermeier, Q., 2012. Hunt for life under Antarctic ice heats up. Nature 491 (7425), 506-507.

Schiermeier, Q., July 2013. Claims of Lake Vostok fish get frosty response.

Schlosser, E., Oerter, H., 2002. Shallow firn cores from Neumayer, Ekströmisen, Antarctica: a comparison of accumulation rates and stable-isotope ratios. Ann. Glaciol. 35, 91-96. 
Schulson, E. M., Duval, P., 2009. Creep and Fracture of Ice. Cambridge University Press, Cambridge.

Schytt, V., 1958. Snow and ice studies in Antarctica. Ph.D. Thesis, University of Stockholm. In: Norwegian-British-Swedish Antarctic Expedition, 1949-1952, Scientific Results 4, Glaciology II. Norsk Polarinstitutt, Oslo.

Seddik, H., Greve, R., Placidi, L., Hamann, I., Gagliardini, O., 2008. Application of a continuum-mechanical model for the flow of anisotropic polar ice to the EDML core, Antarctica. J. Glaciol. 54 (187), 631-642.

Seligman, G., 1936. Snow Structure and Ski Fields. Macmillan, London.

Seligman, G., 1941. The structure of a temperate glacier. Geogr. J. 97 (5), 295315.

Seligman, G., 1949. The growth of the glacier crystal. J. Glaciol. 1 (5), 254-268.

Shirase, N., 2011. Antarctica: The Japanese South Polar Expedition of 1910-12. Bluntisham Books and Erskine Press, Bluntisham.

Siegert, M. J., 2005. Lakes beneath the ice sheet. Annu. Rev. Earth Planet. Sci. $33,247-276$.

Siegert, M. J., Kwok, R., 2000. Ice-sheet radar layering and the development of preferred crystal orientation fabrics between Lake Vostok and Ridge B, central East Antarctica. Earth Planet. Sci. Lett. 179, 227-235.

Stafford, J. M., Wendler, G., Curtis, J., 2000. Temperature and precipitation of Alaska: 50 year trend analysis. Theor. Appl. Climatol. 67, 33-44. 
Steinemann, S., 1954. Results of preliminary experiments on the plasticity of ice crystals. J. Glaciol. 2, 404-412.

Steinemann, S., 1958. Experimentelle Untersuchungen zur Plastizität von Eis. Beitr. Geol. Schweiz, Hydrol. 10, 1-72, also as Ph.D. Thesis, Swiss Federal Institute of Technology (ETH) Zurich.

Stephenson, P. J., 1967. Some considerations of snow metamorphism in the antarctic ice sheet in the light of ice crystal studies. In: Oura, H. (Ed.), Physics of Snow and Ice. Vol. 1. Hokkaido University Press, Sapporo, pp. 725-740, proceedings of the International Conference on Low Temperature Science, 1966, Sapporo, Japan.

Suwa, M., von Fischer, J. C., Bender, M. L., Landais, A., Brook, E. J., 2006. Chronology reconstruction for the disturbed bottom section of the GISP2 and the GRIP ice cores: Implications for Termination II in Greenland. J. Geophys. Res. 111 (D2), D02101.

Svensson, A., Baadsager, P., Persson, A. r., Sch ø tt Hvidberg, C., SiggardAndersen, M.-L., 2003a. Seasonal variability in ice crystal properties at NorthGRIP: a case study around $301 \mathrm{~m}$ depth. Ann. Glaciol. 37, 119-122.

Svensson, A., Nielsen, S. W., Kipfstuhl, S., Johnsen, S. J., Steffensen, J. P., Bigler, M., Ruth, U., Röthlisberger, R., 2005. Visual stratigraphy of the North Greenland Ice Core Project (NorthGRIP) ice core during the last glacial period. J. Geophys. Res. 110, D02108.

Svensson, A., Schmidt, K. G., Dahl-Jensen, D., Johnsen, S. J., Wang, Y., Kipfs- 
tuhl, J., Thorsteinsson, T., 2003b. Properties of ice crystals in NorthGRIP lateto middle-Holocene ice. Ann. Glaciol. 37, 113-118.

Takata, M., Iizuka, Y., Hondoh, T., Fujita, S., Fuji, Y., Shoji, H., 2004. Stratigraphic analysis of Dome Fuji Antarctic ice core using an optical scanner. Ann. Glaciol. 39, 467-472.

Talalay, P. G., 2012. Russian researchers reach subglacial Lake Vostok in Antarctica. Adv. Polar Sci. 23 (3), 176-180.

Taylor, K. C., Hammer, C. U., Alley, R. B., Clausen, H. B., Dahl-Jensen, D., Gow, A. J., Gundestrup, N. S., Kipfstuhl, J., Moore, J. C., Waddington, E. D., 1993. Electrical conductivity measurements from the GISP2 and GRIP Greenland ice cores. Nature 366, 549-552.

Thorsteinsson, T., Kipfstuhl, J., Eicken, H., Johnsen, S. J., Fuhrer, K., 1995. Crystal size variations in Eemian-age ice from the GRIP ice core, Central Greenland. Earth Planet. Sci. Lett. 131, 381-394.

Thorsteinsson, T., Kipfstuhl, J., Miller, H., 1997. Textures and fabrics in the GRIP ice core. J. Geophys. Res. 102, 26583-26599.

Turchetti, S., Naylor, S., Dean, K., Siegert, M., 2008. On thick ice: scientific internationalism and Antarctic affairs, 1957-1980. Hist. Technol. 24 (4), 351376.

Ueda, H. T., Garfield, D. E., 1970. Deep core drilling at Byrd Station. In: IAHS Red Book 86. International Association of Hydrological Sciences, pp. 53-62. 
Ueltzhöffer, K. J., Bendel, V., Freitag, J., Kipfstuhl, S., Wagenbach, D., Faria, S. H., Garbe, C. S., 2010. Distribution of air bubbles in the EDML and EDC ice cores from a new method of automatic image analysis. J. Glaciol. 56 (196), 339-348.

Underwood, E. E., 1970. Quantitative Stereology. Addison-Wesley, Reading.

Van den Broeke, M. R., König-Langlo, G., Picard, G., Munneke, P. K., Lenaerts, J. T. M., 2009. Surface energy balance, melt and sublimation at Neumayer station (East Antarctica). Antarct. Sci. 22 (1), 87-96.

Vasiliev, N. I., Lipenkov, V. Y., Dmitriev, A. N., Podolyak, A. V., Zubkov, V. M., 2012. Results and characteristics of 5G hole drilling and the first tapping of lake Vostok. Ice and Snow 4 (120), 12-20, in Russian.

Vasiliev, N. I., Talalay, P. G., Bobin, N. E., Chistyakov, V. K., Zubkov, V. M., Krasilev, A. V., Dmitriev, A. N., Yankilevich, S. V., Lipenkov, V. Y., 2007. Deep drilling at Vostok station, Antarctica: history and recent events. Ann. Glaciol. $47,10-23$.

Vasiliev, N. I., Talalay, P. G., Vostok Deep Ice Core Drilling Parties, 2011. Twenty years of drilling the deepest hole in ice. Sci. Drilling 11, 41-45.

Victor, P.-E., Bauer, A., 1961. Correspondence on "Air temperature and precipitation on the Greenland Ice Sheet. J. Glaciol. 3 (29), 949.

Vittuari, L., Vincent, C., Frezzotti, M., Mancini, F., Gandolfi, S., Bitelli, G., Capra, A., 2004. Space geodesy as a tool for measuring ice surface velocity in the Dome $\mathrm{C}$ region and along the ITASE traverse. Ann. Glaciol. 39, 402-408. 
Walker, J. C. F., Waddington, E. D., 1988. Descent of glaciers: some early speculations on glacier flow and ice physics. J. Glaciol. 34 (118), 342-348.

Wang, Y., Azuma, N., 1999. A new automatic ice-fabric analyzer which uses image-analysis techniques. Ann. Glaciol. 29, 155-162.

Wang, Y., Kipfstuhl, S., Azuma, N., Thorsteinsson, T., Miller, H., 2003. Icefabrics study in the upper $1500 \mathrm{~m}$ of the Dome C (East Antarctica) deep ice core. Ann. Glaciol. 37, 97-104.

Wang, Y., Thorsteinsson, T., Kipfstuhl, J., Miller, H., Dahl-Jensen, D., Shoji, H., 2002. A vertical girdle fabric in the NorthGRIP deep ice core, North Greenland. Ann. Glaciol. 35, 515-520.

Watanabe, O., Fujii, Y., Kamiyama, K., Motoyama, H., Furukawa, T., Igarashi, M., Kohno, M., Kanamori, S., Ageta, Y., Nakawo, M., Tanaka, H., Satow, K., Shoji, H., Kawamura, K., Matoba, S., Shimada, W., 1999a. Basic analyses of Dome Fuji Deep Ice Core Part I: Stable oxygen and hydrogen isotope ratios, major chemical compositions and dust concentration. Polar Meteorol. Glaciol. $13,83-89$.

Watanabe, O., Kamiyama, K., Motoyama, H., Fujii, Y., Shoji, H., Satow, K., 1999b. The paleoclimate record in the ice core at Dome Fuji station, East Antarctica. Ann. Glaciol. 29, 176-178.

Wegener, K., 1955. Die Temperatur in grönlandischen Inlandeis. Geofis. Pura Appl. 32, 102-106.

Weidick, A., Bennike, O., 2007. Quaternary glaciation history and glaciology of 
Jakobshavn Isbræ and the Disko Bugt region, West Greenland: a review. Geological Survey of Denmark and Greenland Bulletin 14.

Weikusat, I., de Winter, D. A. M., Pennock, G. M., Hayles, M., Schneijdenberg, C. T. W. M., Drury, M. R., June 2010. Cryogenic EBSD on ice: preserving a stable surface in a low pressure SEM. J. Microsc. 242 (3), 295-310.

Weikusat, I., Kipfstuhl, S., Azuma, N., Faria, S. H., Miyamoto, A., 2009a. Deformation microstructures in an Antarctic ice core (EDML) and in experimentally deformed artificial ice. Low Temp. Sci. 68, 115-123.

Weikusat, I., Kipfstuhl, S., Faria, S. H., Azuma, N., Miyamoto, A., 2009b. Subgrain boundaries and related microstructural features in EDML(Antarctica) deep ice core. J. Glaciol. 55 (191), 461-472.

Weikusat, I., Miyamoto, A., Faria, S. H., Kipfstuhl, S., Azuma, N., Hondoh, T., 2011. Subgrain boundaries in Antarctic ice quantified by X-ray Laue diffraction. J. Glaciol. 57 (201), 85-94.

Weiss, J., Vidot, J., Gay, M., Arnaud, L., Duval, P., Petit, J. R., 2002. Dome concordia ice microstructure: impurities effect on grain growth. Ann. Glaciol. $35,552-558$.

Wesche, C., Eisen, O., Oerter, H., Schulte, D., Steinhage, D., 2007. Surface topography and ice flow in the vicinity of the EDML deep-drilling site, Antarctica. J. Glaciol. 53 (182), 442-448.

Whitlow, S., Mayewski, P. A., Dibb, J. E., 1992. A comparison of major chemical species seasonal concentration and accumulation at the South Pole and Summit, Greenland. Atmos. Environ. 26A (11), 2045-2054. 
Wilen, L. A., DiPrinzio, C. L., Alley, R. B., Azuma, N., 2003. Development, principles, and applications of automated ice fabric analyzers. Microsc. Res. Technique 62, 2-18.

Wilhelms, F., Sheldon, S. G., Hamann, I., Kipfstuhl, S., 2007. Implications for and findings from deep ice core drillings - an example: The ultimate tensile strength of ice at high strain rates. In: Kuhs, W. F. (Ed.), Physics and Chemistry of Ice (The proceedings of the International Conference on the Physics and Chemistry of Ice held at Bremerhaven, Germany on 23-28 July 2006). No. 311 in The Royal Society of Chemistry Special Publication. pp. 635-639.

Wilson, C. J. L., Russell-Head, D. S., Sim, H. M., 2003. The application of an automated fabric analyzer system to the textural evolution of folded ice layers in shear zones. Ann. Glaciol. 37, 7-17.

Wingham, D. J., Siegert, M. J., Shepherd, A., Muir, A. S., 2006. Rapid discharge connects Antarctic subglacial lakes. Nature 440, 1033-1036.

Woodcock, N. H., 1977. Specification of fabric shapes using an eigenvalue method. Geol. Soc. Amer. Bull. 88, 1231-1236.

Woods, G. A., 1994. Grain growth behavior of the GISP2 ice core from central Greenland. Technical Report 94-002, Pennsylvania State University, Earth System Science Center, University Park, PA.

Young, N. W., 1979. measured velocities of interior East Antarctica and the state of mass balance within the I.A.G.P. area. J. Glaciol. 24 (90), 77-87. 
1661

\section{Appendix A. FIGURE CAPTIONS}

Figure A.1: Maps of Antarctica and Greenland indicating the drilling sites of the ice cores described in this work. The gray zones in Antarctica indicate ice shelves (i.e. floating ice) and the cross marks the Geographic South Pole.

Figure A.2: Summary of the main features of the grain-size profiles and lattice preferred orientations (LPOs) of Greenlandic deep ice cores (for Antarctic ice cores, see Fig. A.3). Grain sizes are described by the average grain cross-sectional area and the LPOs by $c$-axis pole figures. The symbols $\pi m$ and $\sim \sim \sim$ denote ice frozen to bed and detected subglacial water at bed, respectively (cf. Table B.1). Notice that the profiles and pole figures summarized here are mere outlines that do not display the details and variability of the original data, available in the following references. Camp Century: Herron and Langway (1982). Dye 3: Herron et al. (1985); Langway et al. (1988). GRIP: Thorsteinsson et al. (1997). GISP2: Gow et al. (1997). NGRIP: Wang et al. (2002); Svensson et al. (2003b).

Figure A.3: Summary of the main features of the grain-size profiles and lattice preferred orientations (LPOs) of Antarctic deep ice cores (for Greenlandic ice cores and further explanations, see Fig. A.2). Notice that the profiles and pole figures summarized here are mere outlines that do not display the details and variability of the original data, available in the following references. Byrd Station: Gow and Williamson (1976). Vostok: Lipenkov et al. (1989). EDC: EPICA community members (2004); Durand et al. (2009). EDML: Seddik et al. (2008); Weikusat et al. (2009b). Dome F: Azuma et al. $(1999,2000)$. 
Figure A.4: Modern methods for visualization of multiscale structures of polar ice on the field. Top left: Microstructure Mapping ( $\mu \mathrm{SM}$ ) mosaic image of two cloudy bands in the bubble-hydrate transition zone (EDML, $954 \mathrm{~m}$ depth). The high concentration of microinclusions make the cloudy bands appear darker than the surrounding ice in this image. Contrasting differences in average grain size and shape are evident between the cloudy and "clean" ice. Bright objects are air hydrates preserved inside the ice, while black objects are air bubbles, or decomposing air hydrates on the sample surface. Scale bar: $1 \mathrm{~mm}$. Right: Linescan image of a one-meter long ice core piece (EDML, 1092-1093 m depth). Notice that linescan images are produced by light scattering from the side, against a dark background, and are therefore negative pictures of the core. Brighter bands indicate stronger light scattering due to a higher concentration of impurities (viz. cloudy bands). (From Faria et al., in preparation). Bottom left: Automatic Fabric Analyser (AFA) mosaic trend image of a thin section of Greenlandic ice (NEEM, $822.3 \mathrm{~m}$ depth). The color and brightness describe respectively the azimuth and colatitude of the $c$-axis orientation. Scale bar: $10 \mathrm{~mm}$. 


\section{Appendix B. TABLES}

1663 (See next page) 


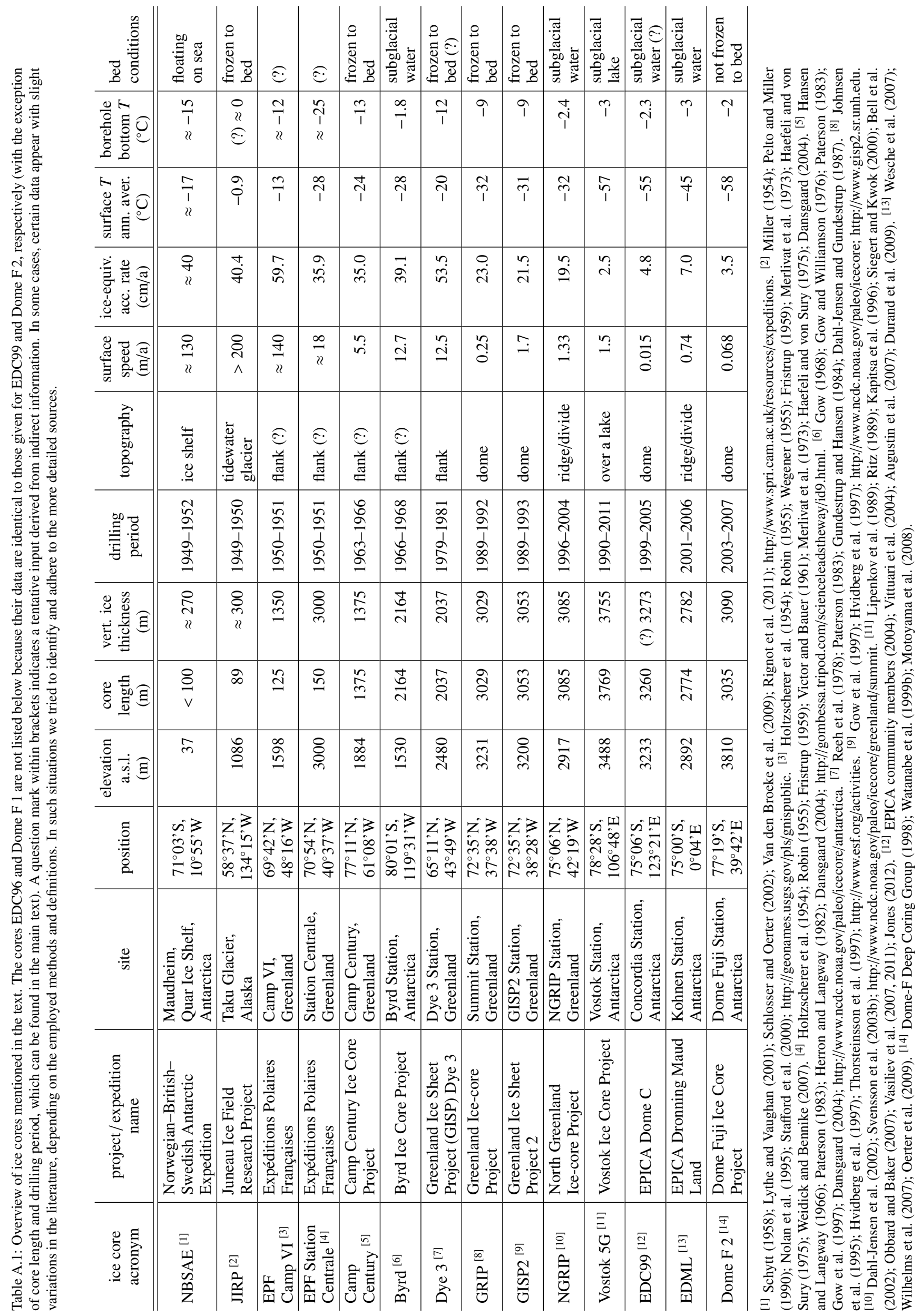


Table A.2: Summary of the most essential features of the deep ice cores dis-

cussed in this work.

\begin{tabular}{|c|c|}
\hline ice core & feat \\
\hline NBSAE & $\begin{array}{l}\text { - First deep ice core from Antarctica. } \\
\text { - Pioneering microstructural investigations of deep polar ice and ice-shelf ice. }\end{array}$ \\
\hline JIRP & - First deep ice core from a polar glacier. \\
\hline $\mathrm{EPF}$ & - First deep ice cores from Greenland. \\
\hline $\begin{array}{l}\text { Camp } \\
\text { Century }\end{array}$ & $\begin{array}{l}\text { - First deep ice core to reach the base of a polar ice sheet. } \\
\text { - First continuous record of structure and chemical composition of a polar ice sheet. } \\
\text { - Clustering of c-axes is stronger in fine-grained layers with high impurity content (cloudy bands). }\end{array}$ \\
\hline Byrd & $\begin{array}{l}\text { - Established the tripartite paradigm. } \\
\text { - Systematic study of cloudy bands. } \\
\text { - Consistent relation between grain sizes, } c \text {-axis orientations, and impurity content: the higher the } \\
\text { impurity content, the smaller the grains and the stronger the } c \text {-axis clustering. } \\
\text { - First problems with subglacial water upwelling. }\end{array}$ \\
\hline Dye 3 & $\begin{array}{l}\text { - Established new standards of organization and efficiency for deep ice core field studies. } \\
\text { - Strong correlation between impurity content and grain size, but no clear relation to } c \text {-axis preferred } \\
\text { orientations. }\end{array}$ \\
\hline GRIP & $\begin{array}{l}\text { - First multi-national European deep ice-core drilling project. } \\
\text { - Clear correlation between impurity content and grain size, but no definite relation to } c \text {-axis preferred } \\
\text { orientations, in agreement with Dye } 3 \text {. } \\
\text { - Microstructural similarity with GISP } 2 \text { and previous cores was invoked as corroboration of the } \\
\text { tripartite paradigm. }\end{array}$ \\
\hline GISP2 & $\begin{array}{l}\text { - Discovery of crystal striping and its relation to folding. } \\
\text { - Microstructural similarity with GRIP and previous cores was invoked as corroboration of the } \\
\text { tripartite paradigm. }\end{array}$ \\
\hline NGRIP & $\begin{array}{l}\text { - First multi-continental deep ice-core drilling project. } \\
\text { - First deep ice core to be partially analyzed with an automated Ice-core Line-Scanner (ILS). } \\
\text { - First deep ice core to be partially analyzed with the method of Microstructure Mapping }(\mu \mathrm{SM}) \text {. } \\
\text { - Evidences that the microstructure of polar ice even at shallow depths is usually not in equilibrium, in } \\
\text { contradiction to the premises of the tripartite paradigm. }\end{array}$ \\
\hline Vostok & $\begin{array}{l}\text { - Longest ice core ever drilled. } \\
\text { - First deep ice core from the top of a large subglacial lake. } \\
\text { - Remarkably regular microstructure points to an ice flow above the lake comparable to that of ice } \\
\text { shelves (insignificant horizontal simple shearing) and negligible dynamic recrystallization. } \\
\text { - Further support to the correlation between grain size and impurity content. }\end{array}$ \\
\hline EDC & $\begin{array}{l}\text { - Oldest ice to date. } \\
\text { - Further discrepancies between the observed ice microstructure and the tripartite paradigm. } \\
\text { - Evidence of grain-boundary pinning by dust particles, giving further support to the correlation } \\
\text { between grain size and impurity content. }\end{array}$ \\
\hline EDML & $\begin{array}{l}\text { - First ice core to have continuous and thorough records of visual stratigraphy (via ILS) and } \\
\text { microstructure (via } \mu \mathrm{SM} \text { ) in microscopic resolution. } \\
\text { - Evidence of strain accommodation by microscopic grain-boundary sliding via microshear in warm } \\
\text { cloudy bands at the MIS5e-MIS6 transition. } \\
\text { - Evidence of dynamic recrystallization throughout the core, including the firn layer, in direct } \\
\text { contradiction to the tripartite paradigm. } \\
\text { - Evidence that non-basal dislocations play a decisive role in heterogeneous strain accommodation } \\
\text { through the formation of subgrain boundaries. }\end{array}$ \\
\hline Dome F & $\begin{array}{l}\text { - Deepest and oldest ice from the Atlantic Sector of Antarctica to date. } \\
\text { - First deep ice core (Dome F 1) to be crystallographically investigated with an Automatic Fabric } \\
\text { Analyzer (AFA). } \\
\text { - Clustering of c-axes is weaker in layers with high impurity content and small grain sizes, in direct } \\
\text { contrast to Camp Century and Byrd. } \\
\text { - Possible activation of diffusion creep at low temperatures and stresses within cloudy bands. }\end{array}$ \\
\hline
\end{tabular}



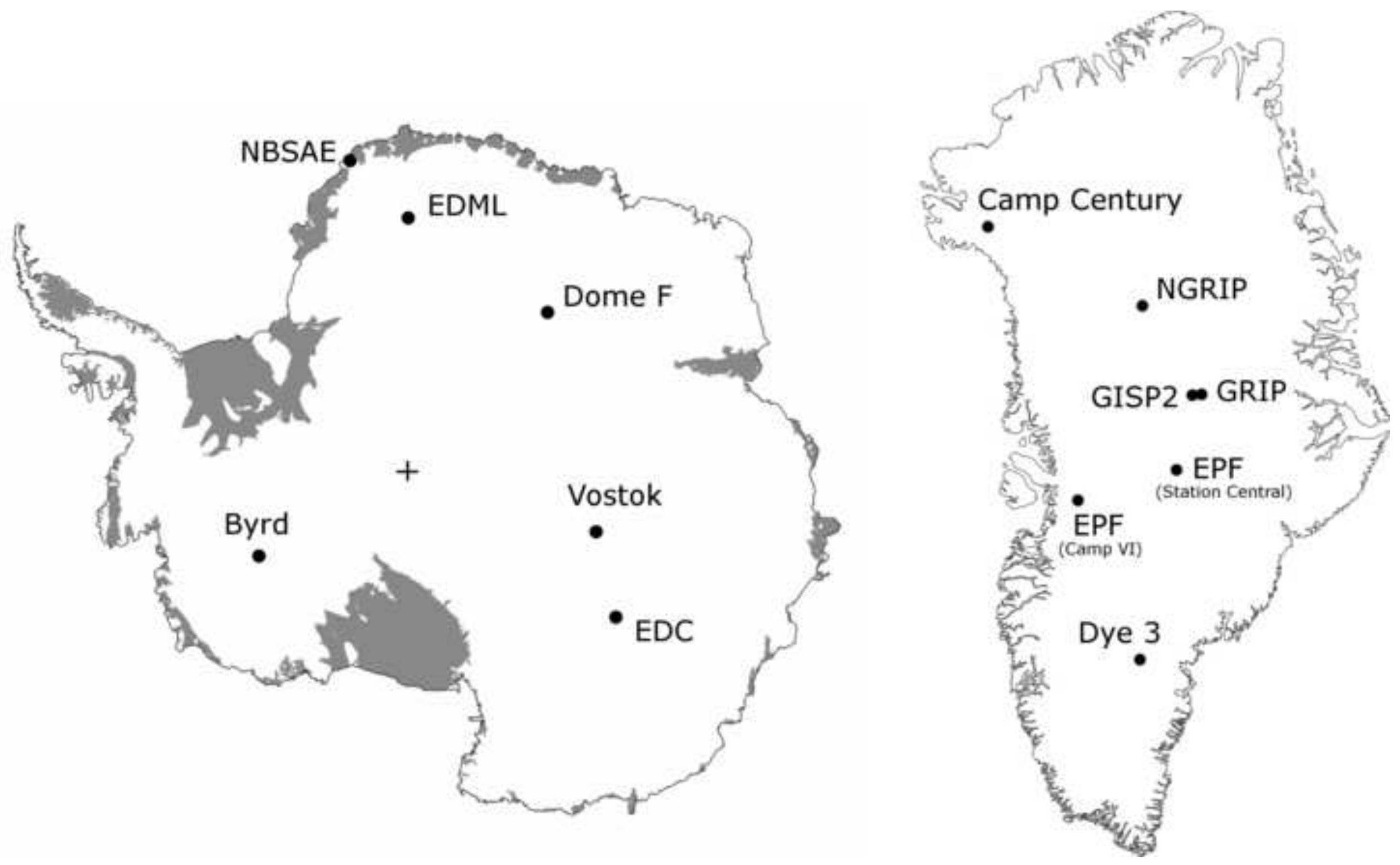

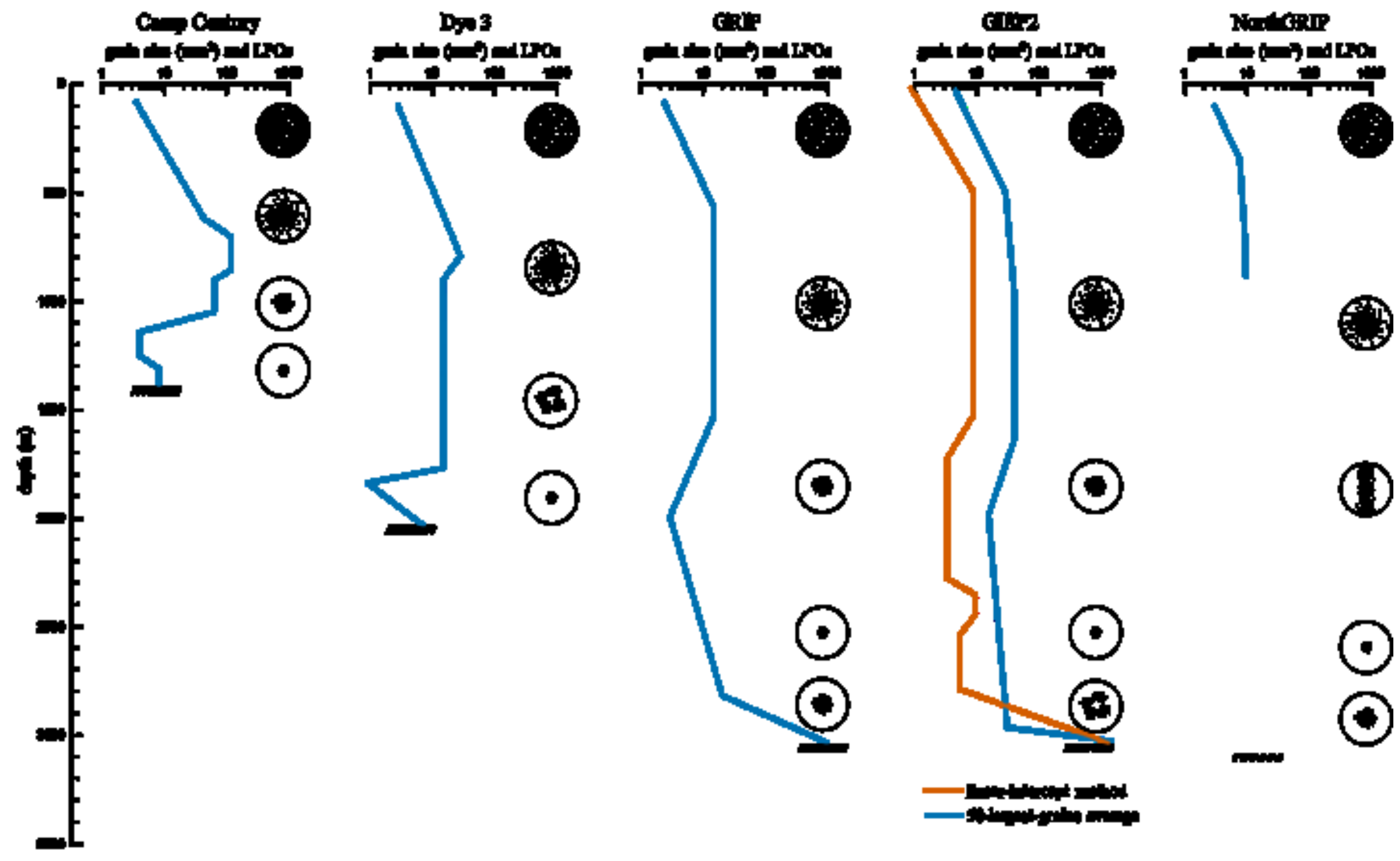

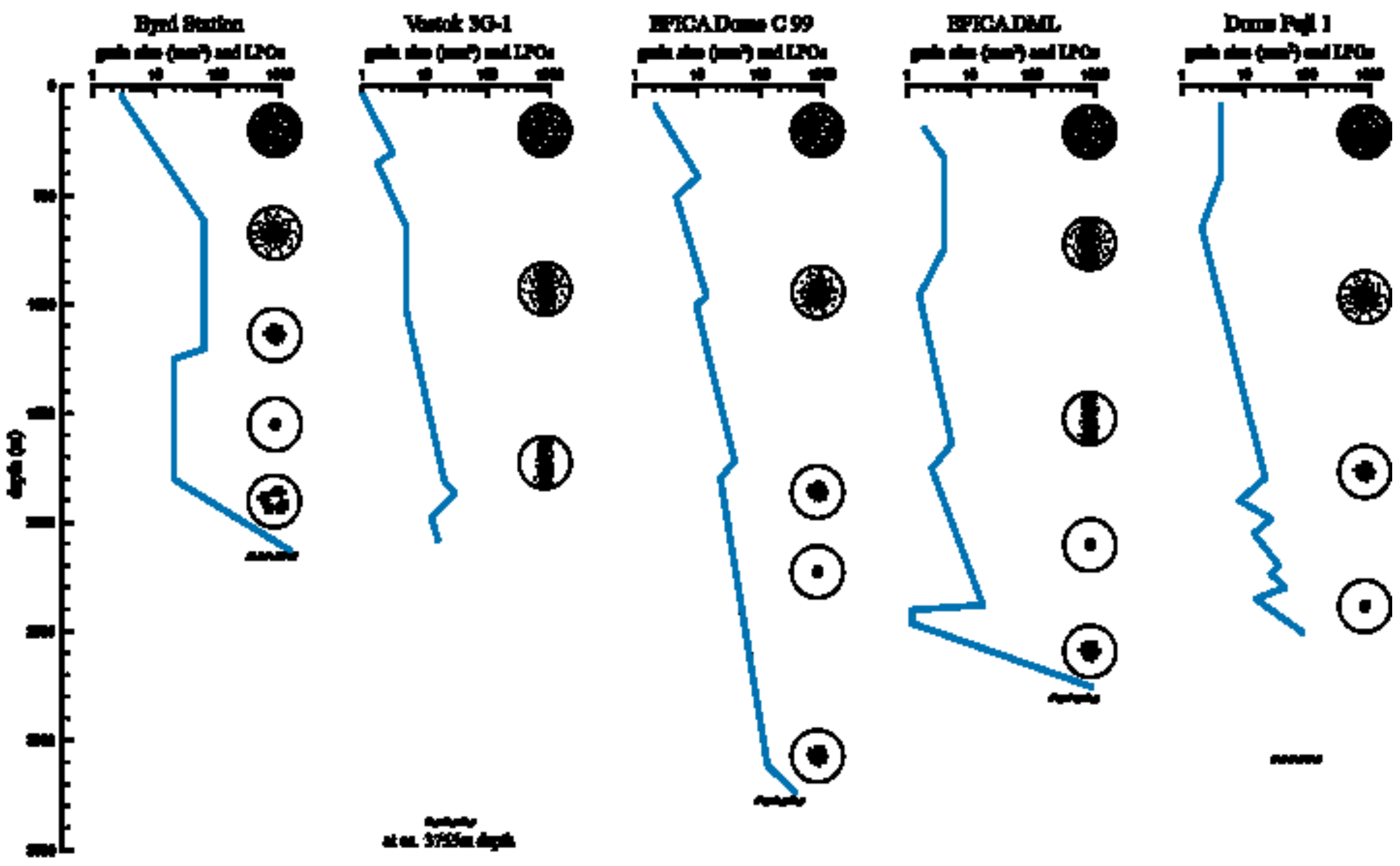

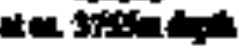


Figure 4

Click here to download high resolution image
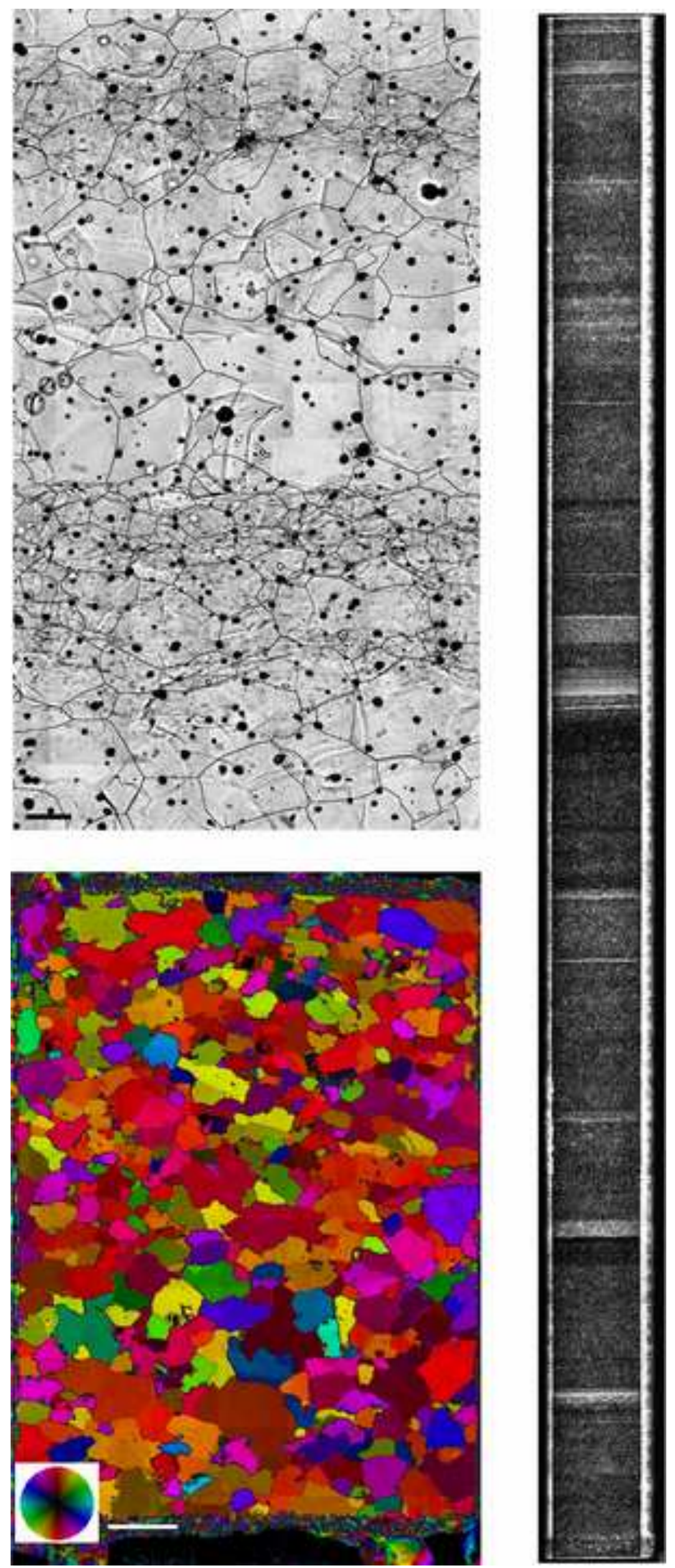
KML File (for GoogleMaps)
Click here to download KML

Click here to download KML File (for GoogleMaps): IceCorePositions_new.kml

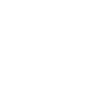

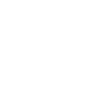

$\sqrt{2}$

$\sqrt{3}$

(1)

$\sqrt{2}$

.

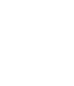

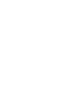
.

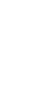
. 